\title{
GPS-derived ground deformation (2005-2014) within the Gulf of Mexico region referred to a stable Gulf of Mexico reference frame
}

\author{
Jiangbo Yu ${ }^{1}$ and Guoquan Wang ${ }^{2}$ \\ ${ }^{1}$ School of Earth Science and Geological Engineering, Sun Yat-sen University, Guangzhou, China \\ ${ }^{2}$ Department of Earth and Atmospheric Sciences, National Center for Airborne LiDAR Mapping, University of Houston, \\ Houston, Texas, USA
}

Correspondence to: Jiangbo Yu (yujb6@mail.sysu.edu.cn)

Received: 27 August 2015 - Published in Nat. Hazards Earth Syst. Sci. Discuss.: 3 November 2015

Revised: 10 June 2016 - Accepted: 21 June 2016 - Published: 7 July 2016

\begin{abstract}
This study investigates current ground deformation derived from the GPS geodesy infrastructure in the Gulf of Mexico region. The positions and velocity vectors of 161 continuous GPS (CGPS) stations are presented with respect to a newly established local reference frame, the Stable Gulf of Mexico Reference Frame (SGOMRF). Thirteen long-term ( $>5$ years) CGPS are used to realize the local reference frame. The root mean square (RMS) of the velocities of the 13 SGOMRF reference stations achieves $0.2 \mathrm{~mm} \mathrm{yr}^{-1}$ in the horizontal and $0.3 \mathrm{~mm} \mathrm{yr}^{-1}$ in the vertical directions. GPS observations presented in this study indicate significant land subsidence in the coastal area of southeastern Louisiana, the greater Houston metropolitan area, and two cities in Mexico (Aguascalientes and Mexico City). The most rapid subsidence is recorded at the Mexico City International airport, which is up to $26.6 \mathrm{~cm} \mathrm{yr}^{-1}$ (2008-2014). Significant spatial variation of subsidence rates is observed in both Mexico City and the Houston area. The overall subsidence rate in the Houston area is decreasing. The subsidence rate in southeastern Louisiana is relatively smaller $\left(4.0-6.0 \mathrm{~mm} \mathrm{yr}^{-1}\right)$ but tends to be steady over time. This poses a potential threat to the safety of coastal infrastructure in the long-term.
\end{abstract}

\section{Introduction}

The Gulf of Mexico (GOM) region has been the heart of the U.S. energy industry because of substantial oil and gas deposits along the coast and offshore of the GOM. It is heavily populated and vulnerable to local ground deformation (faulting, subsidence, uplift) and relative sea-level rise (e.g., Day et al., 1995; Kolker et al., 2011; Thatcher et al., 2013). Land subsidence and faulting problems in the GOM region have been frequently investigated by different research groups using GPS observations (e.g., Dokka, 2011; Engelkemeir et al., 2010; Kearns et al., 2015; Khan et al., 2014; Osmanolu et al., 2011; Wang and Soler, 2013). However, it is difficult to align the results from these research groups because they used different data sets collected by different organizations during different time periods. Furthermore, they focused on localized ground deformation and applied different reference points or frames. This study aims to establish a unified local geodetic reference frame, the Stable Gulf of Mexico Reference Frame (SGOMRF), to investigate the current ground deformation within the whole GOM region during the past decade (2005-2014). Observations of 161 high-quality continuous GPS stations among 450 active long-term GPS stations (Fig. 1) are investigated in this study. Land subsidence and faulting in the Houston region, Mexico City, and the southeastern Louisiana region are discussed and compared.

\section{GPS data processing}

This study applies the precise point positioning (PPP) method, for solving the 24-hour average position of a GPS antenna. PPP is based on the processing of the following ionosphere-free combinations of the undifferenced code and phase observations (Zumberge et al., 1997):

$$
P_{\mathrm{IF}}=\frac{f_{1}^{2} \cdot P(\mathrm{~L} 1)-f_{2}^{2} \cdot P(\mathrm{~L} 2)}{f_{1}^{2}-f_{2}^{2}}=\rho-c \cdot \mathrm{d} T+d_{\text {trop }}
$$




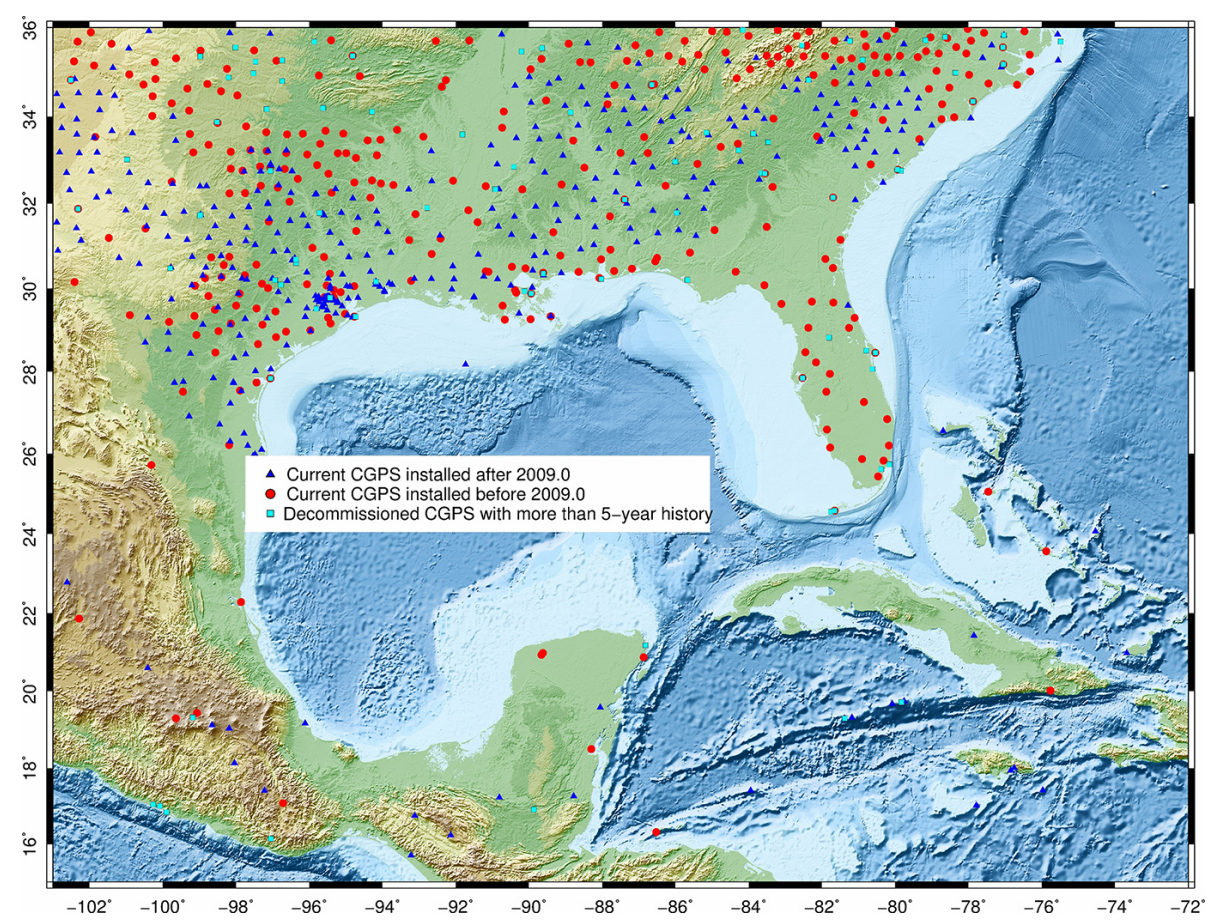

Figure 1. Map showing current CGPS stations in the GOM region. Blue triangles represent current CGPS installed in and after 2009. Red circles represent current CGPS installed before 2009. Grey squares represent decommissioned CGPS that have data spanned for more than 5 years. Data are available through NGS and UNAVCO.

$$
\begin{aligned}
\Phi_{\mathrm{IF}} & =\frac{f_{1}^{2} \cdot \Phi(\mathrm{L} 1)-f_{2}^{2} \cdot \Phi(\mathrm{L} 2)}{f_{1}^{2}-f_{2}^{2}}=\rho-c \cdot \mathrm{d} T+d_{\mathrm{trop}} \\
& +\frac{c f_{1} N_{1}^{\prime}-c f_{2} N_{2}^{\prime}}{f_{1}^{2}-f_{2}^{2}}
\end{aligned}
$$

where $f_{1}$ and $f_{2}$ are the GPS L1 and L2 frequencies; $P(L i)$ and $\Phi(L i)$ are the code and phase observations at the corresponding frequency; $\rho$ is the true range; $c$ is the speed of light; $\mathrm{d} T$ is the receiver clock offset; $d_{\text {trop }}$ is the tropospheric delays; $N_{i}^{\prime}$ is the phase ambiguity term in $\Phi(L i)$. Therefore, the unknown parameters estimated in PPP include position coordinates, phase ambiguity, receiver clock offset and the tropospheric delays. GNSS-Inferred Positioning System and Orbit Analysis Simulation Software (GIPSYOASIS) package (V6.3) developed at the Jet Propulsion Laboratory (JPL) is applied for calculating daily positions. The GIPSY-OASIS package provides single receiver phase ambiguity fixed PPP solutions. The single receiver phase ambiguity method uses the wide lane and phase bias estimates obtained from a global network of ground GPS stations to perform ambiguity-resolved PPP resolution (Bertiger et al., 2010). The major parameters estimated and key models applied in the PPP processing include: the VMF1 troposphere mapping model (Boehm et al., 2006), second-order ionospheric delay (Kedar, 2003), the ocean tidal loading model FES2004 (Lyard et al., 2006) calculated through the free online service operated by Onsala Space Observatory, Sweden (Free ocean tide loading provider, 2015), tropospheric gra- dient (Bar-Sever et al., 1998), zenith troposphere delay as a random walk with variance of $5 \times 10^{-8} \mathrm{~km} \mathrm{~s}^{-1}$, gradient troposphere wet delay as a random walk with variance of $5 \times 10^{-9} \mathrm{~km} \mathrm{~S}^{-1}$, and receiver clock as white noise with updates every measurement epoch. Station coordinates are initially provided in the loose frame of the JPL's fiducial-free GPS orbits. The coordinates are then transformed into the International GNSS Service Reference Frame of 2008 (IGS08) using the daily seven transformation parameters that are delivered with the JPL's orbit products.

The PPP processing conducts all calculations within an Earth-centered-Earth-fixed (ECEF) geocentric coordinate system $(x, y$, and $z)$. In order to track land surface deformation, the ECEF geocentric coordinates are converted to cartographic (northing, easting, and ellipsoidal height) coordinates, which are referred to the GRS-80 ellipsoid. The threecomponent daily positional time series indicates the change of ground surface over time at different directions. The three components represent: north, east, and up. The up component (subsidence/uplift) measurements used in this study are obtained by differencing GPS measured ellipsoidal heights referred to the local reference frame described in the next section. Detection of regional-scale land subsidence has historically depended on surveying benchmarks periodically. This has traditionally been accomplished by differencing orthometric heights obtained from spirit leveling. A recent investigation conducted by Wang and Soler (2014) has indicated 
that using ellipsoid and orthometric heights would result in the same practical subsidence measurements. Accordingly, the subsidence values used in this study can be regarded as having the same "physical meaning" as the conventional subsidence measurements obtained from leveling surveys. For each time series, the outliers, defined as the days for which the uncertainty was greater than 2.0 times of the average uncertainty of the entire measurement, were removed (Firuzabadì and King, 2011; Wang, 2011). The uncertainty of each measurement was directly output by the GIPSY-OASIS program. On average, $5 \%$ of the total samples are removed as outliers. The daily positional time series applied in this article are the "cleaned" time series.

\section{Stable Gulf of Mexico Reference Frame (SGMRF)}

In general, a global or a continental-scale reference frame is realized with an approach of minimizing the least square residual velocities of a large number of selected reference stations. In the case of IGS08, 232 globally distributed, and well-performing GPS stations are used (Rebischung et al., 2012). The velocities at GPS sites referred to IGS08 are dominated by tectonic drift. For a regional study, a stable local reference frame is often established through Helmert transformation to exclude tectonic drift (Wang et al., 2013, 2014, 2015a). It facilitates the precise physical interpretation of local ground deformation over time and space. The transformation involves seven parameters including a rotation vector, a translation vector and one scale factor. These seven transformation parameters can be estimated by comparing the positions of a group of selected reference stations referred to the new reference frame with those referred to a well-established reference frame.

In practice, at least three reference stations are needed to obtain the transformation parameters. More reference stations often result in a more reliable coordinate transformation. However, a reference station that is not locally stable will degrade the overall performance of the frame transformation. A stable site is defined as retaining zero velocities (three components) with respect to a specified reference frame. The stability (precision) of a local reference frame is therefore affected by the velocities of stable sites with respect to the reference frame. Thus, the selection of reference stations is critical for establishing a stable local reference frame. In general, there is not a fixed criterion for selecting reference stations. The selection mostly is based on the availability of long-term CGPS stations in the study area. There are over 780 CGPS stations in the GOM region (Fig. 1). As this study uses a secular frame, the linearity of daily positional time series is a critical criteria for selecting reference stations (Blewitt and Lavallée, 2002). Additionally, the geographic distribution of reference stations is also considered. The following specific criteria are initially applied for selecting reference stations:
1. Having segments of data spanning at least 5 years (installed in 2009 or earlier) with no steps (a sharp change of the mean in positional time series caused by an earthquake, equipment change, or other unknown reasons).

2. No considerable subsidence or uplifting (the linear velocity rate of vertical positional time series referred to IGS08 is less than $0.5 \mathrm{~mm} \mathrm{yr}^{-1}$ );

3. having less than $0.1 \mathrm{~mm} \mathrm{yr}^{-1}$ "standard error" $(\sigma)$ of the slope $\left(V_{\text {cal }}, V_{\text {cal }}\right)$ of the geocentric coordinate time series $(x, y$, and $z$ ) referred to IGS08. $\sigma$ is a measure of the error in the precision with which $V_{\text {cal }}$ has been estimated by a linear regression. A smaller $\sigma$ indicates a small margin of error. Approximately $95 \%$ of the time, the true velocity will be contained in the interval between $V_{\text {cal }}-1.96 \times \sigma$ and $V_{\text {cal }}+1.96 \times \sigma$.

The near-coast areas could be affected by subsidence and coastal erosion problems (Simms et al., 2013; Williams et al., 1997; Yu et al., 2014). Accordingly, it is preferred that reference stations be located inland rather than within nearcoast areas. However, in order to balance the overall coverage and geometrical distribution of reference stations, one near-coast station in Florida (RMND) and one near-coast station in Mexico (TAM1) were selected as reference stations (Fig. 2). Uneven distribution of reference sites could lead to biases in frame transformation (Collilieux et al., 2010; Wang et al., 2014). Positional time series affected by steps are identified by an automated edge detection program based on the derivative of Gaussian kernel (Canny, 1986). Initially, 30 CGPS stations were selected as reference stations and the reference frame transformation were calculated. Any station that had a horizontal velocity larger than $0.5 \mathrm{~mm} \mathrm{yr}^{-1}$ with respect to the resulted local reference frame was removed from the group of reference stations and the transformation was recalculated again. Finally, 13 CGPS stations are selected as reference stations for realizing the SGOMRF (Fig. 2).

Two different approaches are often used in geodesy to transform positional time series from one reference frame to another: the daily 7-parameter Helmert transformation (Blewitt et al., 2013) and the 14-parameter similarity transformation. This study applies a 14-parameter transformation approach that has been frequently applied in the geodesy surveying community (e.g., Pearson and Snay, 2012; Wang et al., 2014). The geocentric coordinates of a station with respect to SGOMRF are calculated by the following formulas:

$$
\begin{gathered}
X(t)_{\mathrm{SGOMRF}}=T_{X}(t)+[1+s(t)] \cdot X(t)_{\mathrm{IGS} 08}+R_{Z}(t) \\
\cdot Y(t)_{\mathrm{IGS} 08}-R_{Y}(t) \cdot Z(t)_{\mathrm{IGS} 08} \\
\begin{aligned}
Y(t)_{\mathrm{SGOMRF}} & =T_{Y}(t)-R_{Z}(t) \cdot X(t)_{\mathrm{IGS} 08}+[1+s(t)] \\
& \cdot Y(t)_{\mathrm{IGS} 08}+R_{X}(t) \cdot Z(t)_{\mathrm{IGS} 08}
\end{aligned}
\end{gathered}
$$




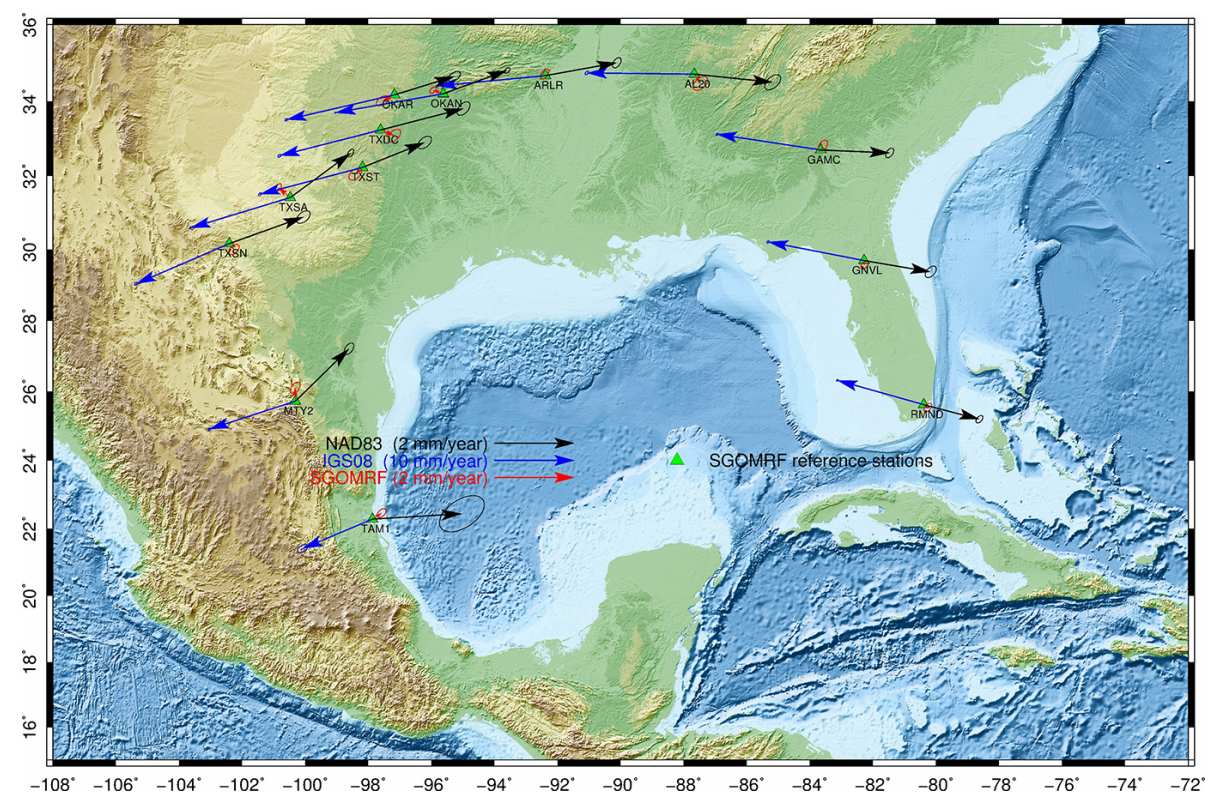

Figure 2. Map showing the locations and velocity vectors with $95 \%$ confidence ellipses of the 13 reference stations used to define SGOMRF. Black vectors are referred to NAD83; blue vectors are referred to IGS08; red vectors are referred to SGOMRF.

$$
\begin{gathered}
Z(t)_{\mathrm{SGOMRF}}=T_{Z}(t)+R_{Y}(t) \cdot X(t)_{\mathrm{IGS} 08}-R_{X}(t) \\
\cdot Y(t)_{\mathrm{IGS} 08}+[1+s(t)] \cdot Z(t)_{\mathrm{IGS} 08} .
\end{gathered}
$$

Here, $T_{x}(t), T_{Y}(t)$ and $T_{Z}(t)$ are translations along $x, y$ and $z$ axis; $R_{X}(t), R_{Y}(t)$ and $R_{Z}(t)$ are counterclockwise rotations about three axes; $s(t)$ is a differential scale factor between IGS08 and SGOMRF. These seven parameters at any point in time are specified relative to a reference epoch by the following linear relationships:

$$
\begin{aligned}
& T_{X}(t)=T_{X}\left(t_{0}\right)+\mathrm{d} T_{X} \cdot\left(t-t_{0}\right) \\
& T_{Y}(t)=T_{Y}\left(t_{0}\right)+\mathrm{d} T_{Y} \cdot\left(t-t_{0}\right) \\
& T_{Z}(t)=T_{Z}\left(t_{0}\right)+\mathrm{d} T_{Z} \cdot\left(t-t_{0}\right) \\
& R_{X}(t)=R_{X}\left(t_{0}\right)+\mathrm{d} R_{X} \cdot\left(t-t_{0}\right) \\
& R_{Y}(t)=R_{Y}\left(t_{0}\right)+\mathrm{d} R_{Y} \cdot\left(t-t_{0}\right) \\
& R_{Z}(t)=R_{Z}\left(t_{0}\right)+\mathrm{d} R_{Z} \cdot\left(t-t_{0}\right) \\
& s(t)=s\left(t_{0}\right)+\mathrm{d} s \cdot\left(t-t_{0}\right) .
\end{aligned}
$$

Here, $t_{0}$ denotes a specific epoch (e.g., 2013.0). $T_{X}\left(t_{0}\right)$, $T_{Y}\left(t_{0}\right), T_{Z}\left(t_{0}\right), R_{X}\left(t_{0}\right), R_{Y}\left(t_{0}\right), R_{Z}\left(t_{0}\right)$ and $s\left(t_{0}\right)$ are the seven transformation parameters at epoch $t_{0}$. The two reference frames are aligned at epoch 2013.0. That means the positional coordinates of a site with respect to both reference frames are identical at this epoch. Thus, the seven transformation parameters at epoch $t_{0}$ are all zeros. $\mathrm{d} T_{X}, \mathrm{~d} T_{Y}, \mathrm{~d} T_{Z}$, $\mathrm{d} R_{X}, \mathrm{~d} R_{Y}, \mathrm{~d} R_{Z}$, and $\mathrm{d} s$ are the first time derivatives of corresponding parameters, which are constant over time. The units of these parameters are meters for translational components, radians for rotational components, $\mathrm{m} \mathrm{yr}^{-1}$ for the rate of translational movement, and radian/year for the rate of rotational components. $s(t)$ is a unitless scale factor. The unit of $\mathrm{d} s$ is $1 /$ year. We use the same procedure as described in Wang et al. (2014) to obtain the 14 parameters. The two reference frames were aligned at the epoch 2013.0. Thus the coordinates of a station at epoch 2013.0 with respect to the two reference frames are identical. As a result, the seven parameters at the epoch 2013.0 for reference frame transformation are all zeros. The seven transformation parameters at epoch 2000.0 were calculated by comparing the coordinates with respect to the two reference frame and solving the parameters in Eq. (3) through least squares estimation. The coordinates with respect to SGOMRF at epoch 2000.0 are assumed to be equal to those at epoch 2013.0 since the sites are considered to have zero velocities with respect to SGOMRF. The rates of these seven parameters over time were calculated using the following formula:

$$
\begin{aligned}
& \mathrm{d} T_{X}=\left(T_{X}(2013.0)-T_{X}(2000.0)\right) / 13.0 \\
& \mathrm{~d} R_{X}=\left(R_{X}(2013.0)-R_{X}(2000.0)\right) / 13.0 \\
& \mathrm{~d} s=(s(2013.0)-s(2000.0)) / 13.0 .
\end{aligned}
$$

Figure 3 depicts the three-component positional time series of two stations (OKAN and SG05) referred to SGOMRF, North American Datum of 1983 (NAD 83) (2011), and IGS08. The NAD 83 is the horizontal control datum for the US, Canada, Mexico, and Central America (Schwarz, 1989; Snay and Soler, 2000). It is widely used as a North American plate-fixed reference frame in the practice of surveying. The continental-scale reference frame has been updated for several times. The most recent realization is referred as NAD83(2011) at epoch 2010.0. The positional coordinates referred to NAD83(2011) are transformed from 
Table 1. Fourteen parameters for reference frame transformations from IGS08 to SGOMRF and from IGS08 to NAD83(2011).

\begin{tabular}{llrr}
\hline Parameter & Unit & $\begin{array}{r}\text { IGS08 to } \\
\text { SGOMRF } \\
t_{0}=2013.0\end{array}$ & $\begin{array}{r}\text { IGS08 to } \\
\text { NAD83(2011) } \\
t_{0}=1997.0\end{array}$ \\
\hline$T_{x}\left(t_{0}\right)$ & $\mathrm{cm}$ & 0.00000 & 99.34300 \\
$T_{y}\left(t_{0}\right)$ & $\mathrm{cm}$ & 0.00000 & -190.33100 \\
$T_{z}\left(t_{0}\right)$ & $\mathrm{cm}$ & 0.00000 & -52.65500 \\
$R_{x}\left(t_{0}\right)^{\mathrm{b}}$ & $\mathrm{mas}^{\mathrm{c}}$ & 0.00000 & 25.91467 \\
$R_{y}\left(t_{0}\right)$ & $\mathrm{mas}$ & 0.00000 & 9.42645 \\
$R_{z}\left(t_{0}\right)$ & $\mathrm{mas}^{\mathrm{d}}$ & 0.00000 & 11.59935 \\
$s\left(t_{0}\right)$ & $\mathrm{ppb}^{\mathrm{d}}$ & 0.00000 & 1.71504 \\
$\mathrm{~d} T_{x}$ & $\mathrm{~cm} \mathrm{yr}^{-1}$ & 0.24978 & 0.07900 \\
$\mathrm{~d} T_{y}$ & $\mathrm{~cm} \mathrm{yr}^{-1}$ & -0.12958 & -0.06000 \\
$\mathrm{~d} T_{z}$ & $\mathrm{~cm} \mathrm{yr}^{-1}$ & -0.24124 & -0.13400 \\
$\mathrm{~d} R_{x}$ & $\mathrm{mas} \mathrm{yr}^{-1}$ & 0.10195 & 0.06667 \\
$\mathrm{~d} R_{y}$ & $\mathrm{mas} \mathrm{yr}^{-1}$ & -0.61808 & -0.75744 \\
$\mathrm{~d} R_{z}$ & $\mathrm{mas} \mathrm{yr}^{-1}$ & -0.00673 & -0.05133 \\
$\mathrm{~d} s$ & $\mathrm{ppb} \mathrm{yr}^{-1}$ & 0.04980 & -0.10201 \\
\hline
\end{tabular}

${ }^{\mathrm{a}}$ Source: Pearson and Snay (2012), Table 7; ${ }^{\mathrm{b}}$ counterclockwise rotations of axes are positive; ${ }^{\mathrm{c}}$ mas $=$ milliarc second, radians to mas coefficient: 206264806.24709636; mas to radians coefficient: $4.848137 \times 10^{-9}$;

${ }^{\mathrm{d}} \mathrm{ppb}=$ parts per billion.

IGS08 with Eqs. (3) and (4) and 14 parameters provided by Pearson and Snay (2012) (Table 1). Both sites retain nearzero velocities $\left(<0.5 \mathrm{~mm} \mathrm{yr}^{-1}\right)$ with respect to the local reference frame SGOMRF. The three-component velocities derived from the 10-year (2004-2014) continuous observations at OKAN are $-2.3 \mathrm{~mm} \mathrm{yr}^{-1}$ (north), $-13.4 \mathrm{~mm} \mathrm{yr}^{-1}$ (east), and $0.2 \mathrm{~mm} \mathrm{yr}^{-1}$ (up) with respect to IGS08 and $0.6 \mathrm{~mm} \mathrm{yr}^{-1}$ (north), $1.6 \mathrm{~mm} \mathrm{yr}^{-1}$ (east), and $-0.2 \mathrm{~mm} \mathrm{yr}^{-1}$ (up) with respect to NAD83. The velocities at SG05 are generally the same (Fig. 3). The horizontal velocity $\left(1.5 \mathrm{~cm} \mathrm{yr}^{-1}\right)$ referred to IGS08 can be explained by the tectonic movement of the GOM region with respect to the global reference frame. However the minor horizontal movements $\left(\sim 2 \mathrm{~mm} \mathrm{yr}^{-1}\right)$ with respect to the supposedly continent-fixed reference frame (NAD83) can be misleading. The same minor horizontal movements with respect to NAD83(2011) can also be observed at the 13 reference stations, even though the nearzero velocities with respect to SGOMRF indicate they are stable (Fig. 2). The coherent horizontal movement referred to the NAD83(2011) could be incorrectly interpreted as the result of local active faulting. In fact, the $2 \mathrm{~mm} \mathrm{yr}^{-1}$ horizontal velocity does not represent any local ground movement. It indicates the low precision of the NAD83 reference frame within the GOM region. The instability of the continentalscale reference frame will overlook or bias minor local horizontal ground deformation signals.

The root-mean-square (RMS) value of the linear velocities of these 13 reference stations are $0.15 \mathrm{~mm} \mathrm{yr}^{-1}$ for the east component, $0.19 \mathrm{~mm} \mathrm{yr}^{-1}$ for the north component, and $0.25 \mathrm{~mm} \mathrm{yr}^{-1}$ for vertical component with respect to the local
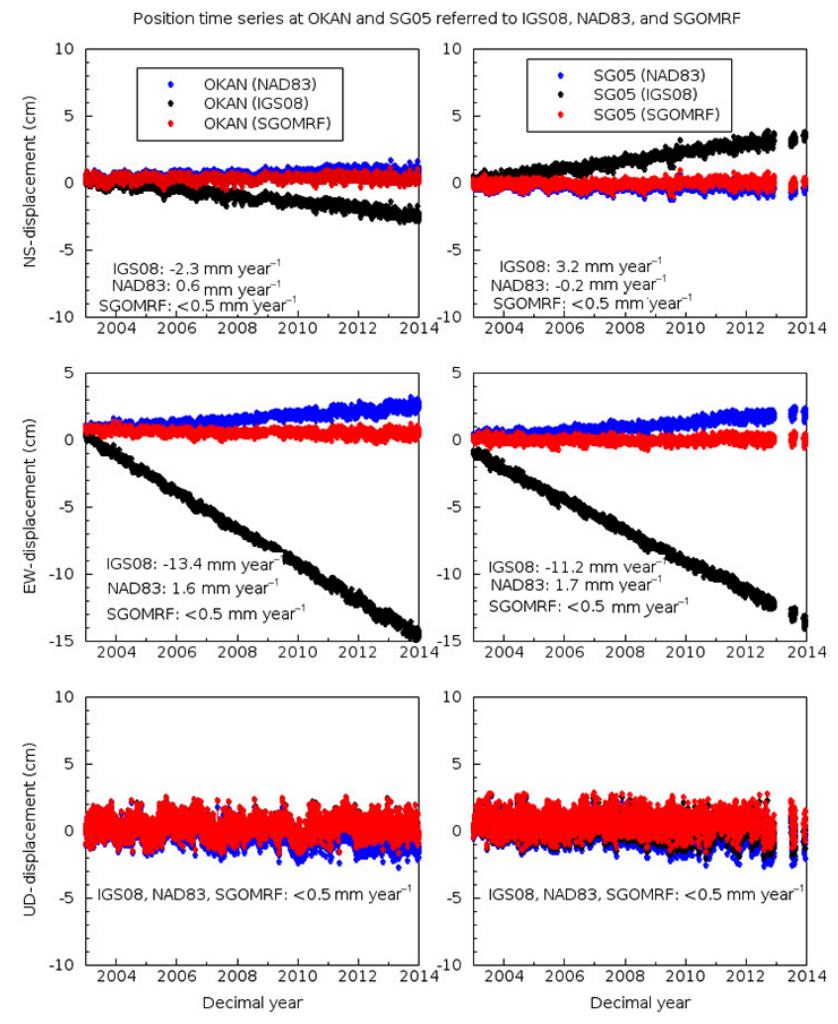

Figure 3. Comparisons of time series at two CGPS sites, OKAN and SG05, referred to three reference frames: IGS08 (black), NAD83 (blue), and SGOMRF (red). OKAN is located at Antlers, Oklahoma. SG05 is located at Melbourne, Florida.

reference frame (SGOMRF). Table 2 lists the average coordinates of these 13 reference stations referred to SGOMRF at epoch 2013.0 and the RMS values of corresponding residual time series. These RMS values are often regarded as the precision (repeatability) of the daily positions. The results illustrated in Table 2 suggest that the PPP solutions obtained in this study achieve $2 \mathrm{~mm}$ horizontal precision and $7 \mathrm{~mm}$ vertical precision, which is comparable with the overall precision of GIPSY-OASIS PPP solutions. Bertiger et al. (2010) reported that the single receiver ambiguity fixed PPP solutions achieved overall $2 \mathrm{~mm}$ horizontal precision and $6 \mathrm{~mm}$ vertical precision for the 106 worldwide IGS reference stations. It should be noticed that the 14-parameter transformation processing did not improve the precision of velocity estimates since a linear regression model was applied to the changes of the scale, three translational, and three rotational motions in time.

\section{Horizontal ground deformation}

This study investigated GPS data from 148 stations that have step-free time spans of longer than 4 years, and transform the daily positional time series to the local reference frame 
Table 2. Geodetic coordinates (longitude, latitude, ellipsoidal height) of the 13 reference sites with respect to SGOMRF and their RMS accuracy (repeatability).

\begin{tabular}{|c|c|c|c|c|c|c|}
\hline \multicolumn{4}{|c|}{ Geodetic coordinates (SGOMRF) } & \multicolumn{3}{|c|}{ RMS accuracy } \\
\hline Station & $\begin{array}{r}\text { Longitude } \\
\text { (degree) }\end{array}$ & $\begin{array}{l}\text { Latitude } \\
\text { (degree) }\end{array}$ & $\begin{array}{r}\text { Ellipsoid } \\
\text { height } \\
(\mathrm{m})\end{array}$ & $\begin{array}{l}\text { North } \\
(\mathrm{mm})\end{array}$ & $\begin{array}{l}\text { East } \\
(\mathrm{mm})\end{array}$ & $\begin{array}{c}\mathrm{Up} \\
(\mathrm{mm})\end{array}$ \\
\hline AL20 & -87.663 & 34.710 & 131.934 & 1.93 & 1.75 & 7.76 \\
\hline ARLR & -92.383 & 34.673 & 73.224 & 1.98 & 1.36 & 6.94 \\
\hline GNVL & -82.277 & 29.687 & 22.434 & 1.74 & 1.70 & 5.90 \\
\hline GAMC & -83.649 & 32.702 & 91.395 & 1.94 & 1.72 & 7.29 \\
\hline MTY2 & -100.313 & 25.716 & 521.864 & 1.97 & 2.09 & 6.31 \\
\hline OKAN & -95.621 & 34.195 & 140.296 & 1.76 & 1.81 & 6.49 \\
\hline OKAR & -97.169 & 34.168 & 235.819 & 1.83 & 2.67 & 6.55 \\
\hline RMND & -80.384 & 25.614 & -15.684 & 1.88 & 1.94 & 6.96 \\
\hline TAM1 & -97.864 & 22.278 & 21.043 & 1.98 & 2.06 & 6.13 \\
\hline TXDC & -97.609 & 33.236 & 255.341 & 1.90 & 1.84 & 6.15 \\
\hline TXSA & -100.473 & 31.414 & 566.086 & 2.08 & 1.86 & 6.25 \\
\hline TXSN & -102.409 & 30.153 & 850.957 & 1.76 & 1.90 & 6.04 \\
\hline TXST & -98.182 & 32.233 & 376.569 & 1.74 & 1.85 & 5.92 \\
\hline Average & & & & 1.88 & 1.89 & 6.51 \\
\hline
\end{tabular}

(Fig. 4). The average horizontal velocity of these 148 stations is below $1 \mathrm{~mm} \mathrm{yr}^{-1}$, which implies that the interior of the GOM region is rigid at the level of sub-millimeter per year. Five long-term GPS stations have been moving horizontally with relatively larger velocities $\left(>2 \mathrm{~mm} \mathrm{yr}^{-1}\right)$. These stations are MMX1 $\left(9.7 \mathrm{~mm} \mathrm{yr}^{-1}\right)$, FSHS $\left(3.4 \mathrm{~mm} \mathrm{yr}^{-1}\right)$, UNIP $\left(2.9 \mathrm{~mm} \mathrm{yr}^{-1}\right)$, TXPR $\left(2.4 \mathrm{~mm} \mathrm{yr}^{-1}\right)$ and ROD1 $\left(2.4 \mathrm{~mm} \mathrm{yr}^{-1}\right)$. Four of these stations are located in wellknown subsidence areas. MMX1 is located in Mexico City, Mexico. FSHS is located in Franklin, Louisiana. UNIP is located in Aguascalientes, Mexico. ROD1 is located in Houston, Texas.

In the case of groundwater withdrawal induced subsidence, a subsidence bowl can be formed by localized aquifer compaction. In such an event, it is possible that GPS stations are pulled horizontally towards the center of the subsidence bowl (e.g., Allis, 2000; Bawden et al., 2001, 2012). Depending on the position of a station relative to the subsidence center, the ratio of horizontal to vertical velocities varies. A station at the edge of the subsidence center will show a relatively large horizontal velocity. A station located closer to the center of subsidence could display large velocities in both the horizontal and vertical components. Around the center of the subsidence feature, the stations will mostly exhibit vertical movement. Figure 5 depicts the three-component positional time series at ROD1, TXCN, and TXLI referred to the local reference frame. TXLI is a stable station located in Liberty County, Texas. ROD1 shows a $2.3 \mathrm{~mm} \mathrm{yr}^{-1}$ horizontal movement towards the northeast. TXCN shows no movement in the horizontal direction. Both ROD1 and TXCN indicate long-term subsidence. According to our previous studies on the current subsidence in the greater Houston metropolitan area (Kearns et al., 2015; Yu et al., 2014), a rapid-subsidence bowl is forming around The Woodlands area. The Woodlands is a vibrant and fast-growing business and entertainment suburban area located $43 \mathrm{~km}$ north of downtown Houston (Fig. 6). Groundwater is the sole water source for residential and business use in this area as of 2014. The subsidence rate in the center of the subsidence bowl is about $25 \mathrm{~mm} \mathrm{yr}^{-1}$ (Kearns et al., 2015). ROD1 is located in the city of Spring, Texas, northern Harris County. The station is $12 \mathrm{~km}$ southwest to The Woodlands area (Fig. 6). The subsidence rate at ROD1 is $17 \mathrm{~mm} \mathrm{yr}^{-1}$ derived from the whole time series from 2007 to 2014. The closely spaced contour lines represent greater spatial variation of subsidence rates in this developing subsidence bowl. The horizontal velocity vector indicates that ROD1 is affected by the differential subsidence. TXCN is located in the city of Conroe, Texas, which is $21 \mathrm{~km}$ north of The Woodlands. The positional time series (20082014) of TXCN does not indicate any considerable horizontal movement $\left(<1 \mathrm{~mm} \mathrm{yr}^{-1}\right)$. However, steady land subsidence with a rate of $16 \mathrm{~mm} \mathrm{yr}^{-}$" has been recorded at this site. The contour lines in this area are spaced far apart. The different vertical-to-horizontal velocity ratio suggests that TXCN is located at a more uniformly subsiding, therefore, flat area. whereas ROD1 is more likely located along the steep sidewall of the developing subsidence bowl. The comparison of the three-component positional time series of ROD1 with those of TXCN illustrates a good example of horizontal velocity variations around a subsidence bowl.

A similar movement pattern at two CGPS sites around a subsidence bowl is also observed in Mexico City (Fig. 7). 


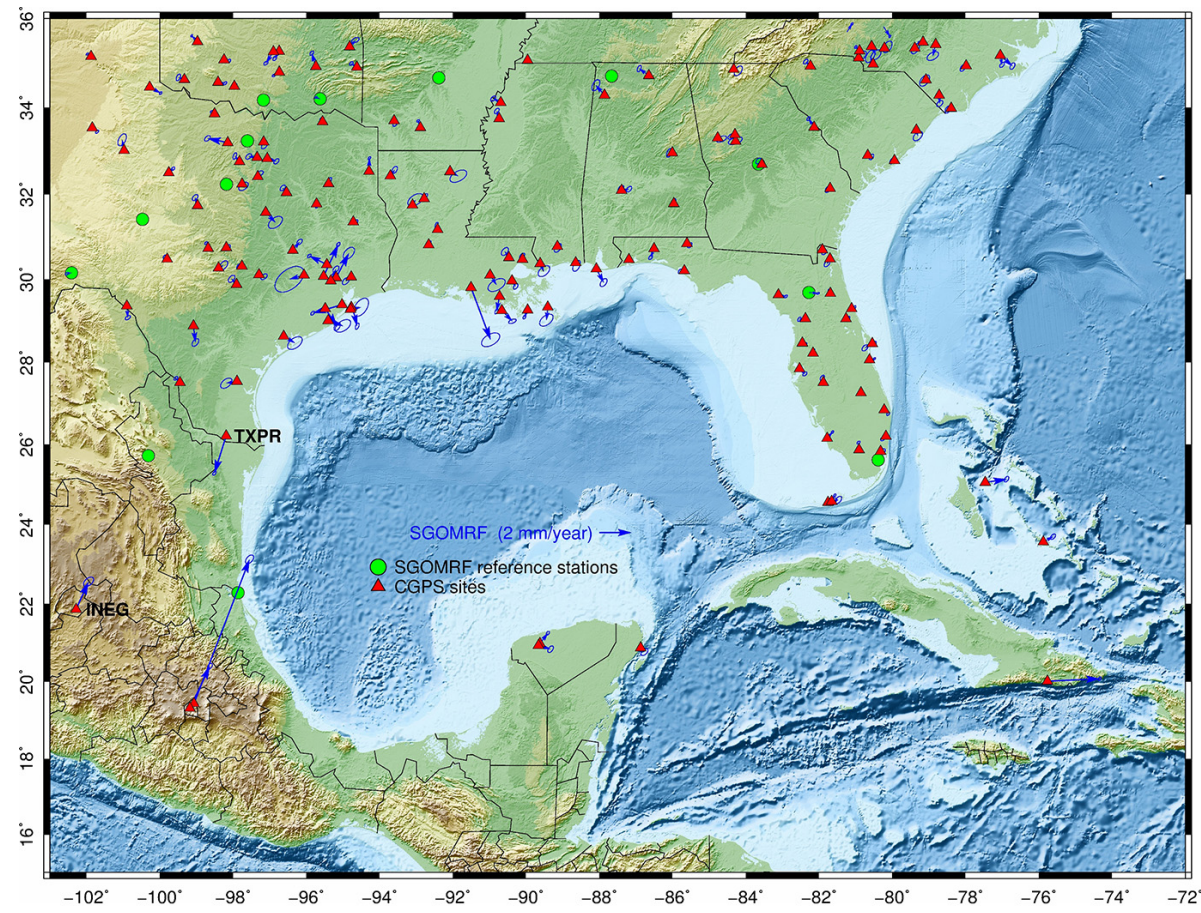

(a)

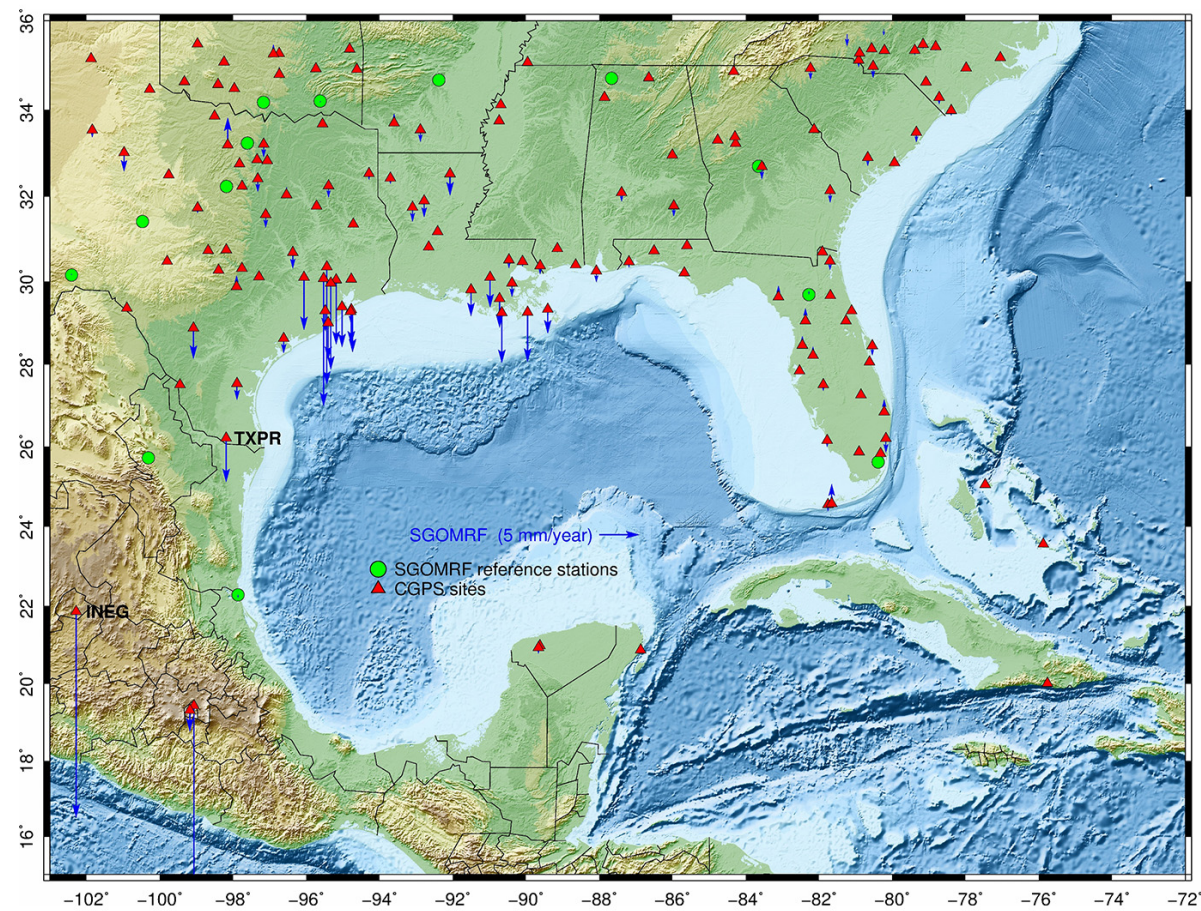

(b)

Figure 4. (a) Horizontal velocity with $95 \%$ confident ellipses and (b) vertical velocity vectors of 148 CGPS stations (> 4 years) in the Gulf of Mexico region. Green dots represent the 13 reference stations. The blue vectors represent the average velocities referred to SGOMRF. 


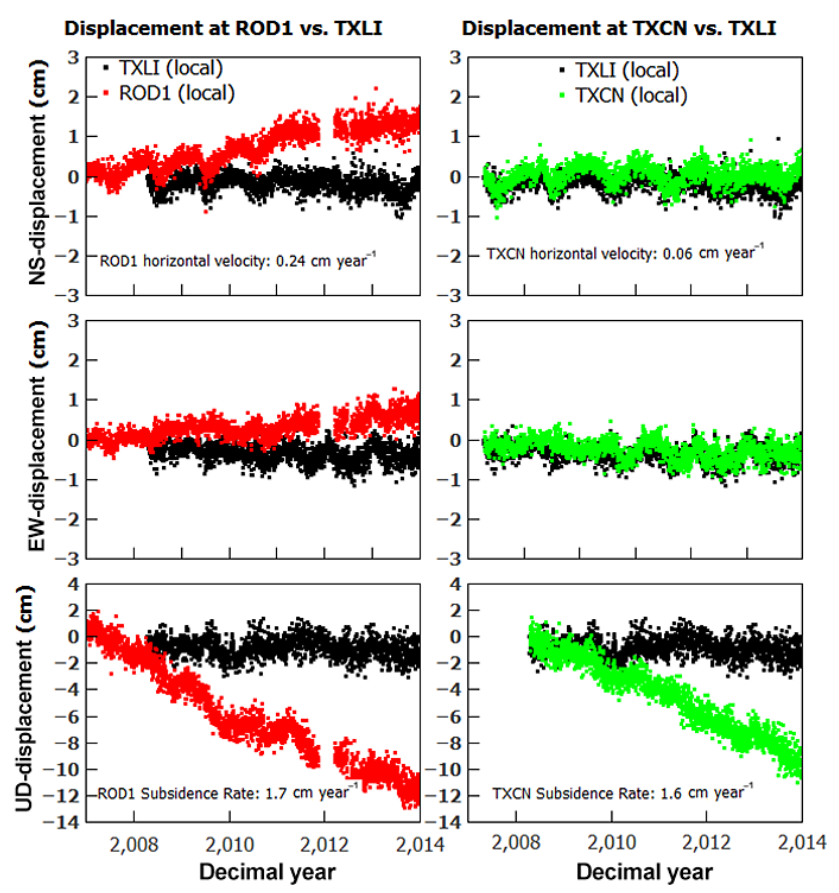

Figure 5. Displacement time series of two rapidly subsiding CGPS sites (ROD1 and TXCN) in northern Houston. The displacement time series of a stable site (TXLI) are plotted for comparative purposes. Locations of these three stations are plotted in Fig. 6. The reference frame is SGOMRF.

MMX1 is located in the Mexico International Airport, eastern Mexico City. UNIP is located at the Universidad Nacional Autónoma de México, southwestern Mexico City. UNIP records a smaller rate of $2.9 \mathrm{~mm} \mathrm{yr}^{-1}$ towards the northeast. Observations from InSAR indicated that subsidence rates in Mexico City increased eastwards towards the center of the Basin of Mexico (Chaussard et al., 2014). The horizontal movements of MMX1 and UNIP agree well with the subsidence bowl illustrated by the InSAR data: both UNIP and MMX1 are moving toward the center of the subsidence bowl. MMX1 is located much closer to the center and therefore has demonstrated higher rates of horizontal motion (Fig. 7).

Figure 8 depicts that FSHS, a permanent GPS station (2010-2014) located at Franklin, Louisiana, has been moving toward the southeast at a rate of $3.4 \mathrm{~mm} \mathrm{yr}^{-1}$. The antenna of FSHS is mounted on a reinforced concrete building located at Franklin High School. Subsidence at this site is consistent and could lead to more serious problem over the long term. There is no known excessive groundwater withdrawal issue in this area. It is not likely that the horizontal movement is associated with an on-going subsidence bowl. Our other GPS sites (AWES, DSTR, HOUM, GRIS, BVHS, LMCN) in southeastern Louisiana also demonstrate movements southward with rates smaller than $1 \mathrm{~mm} \mathrm{yr}^{-1}$. Dokka et al. (2006) observed a similar southward displacement and

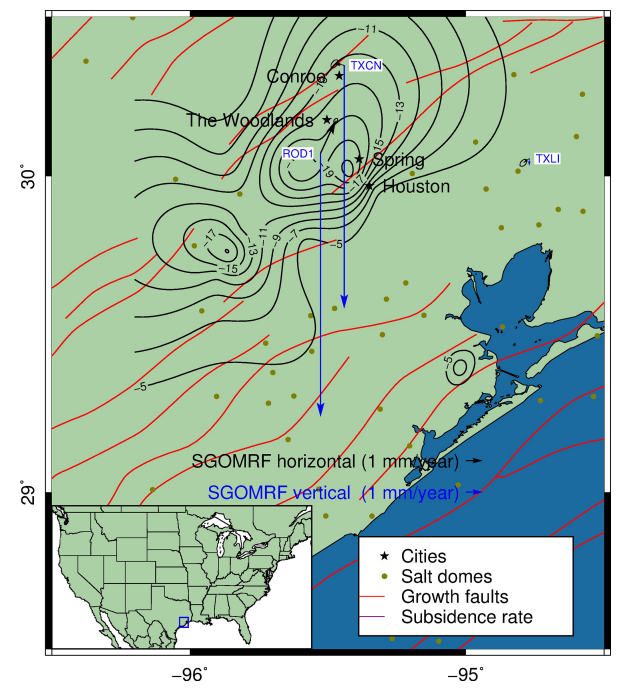

Figure 6. Locations of three CGPS stations and cities within the greater Houston area. Black and blue velocity vectors represent horizontal and vertical velocities with respect to SGOMRF, respectively. Red lines are growth faults and yellow dots are salt domes (Garrity and Soller, 2009). Contours lines are subsidence rate from 2005 to 2012 (Kearns et al., 2015).

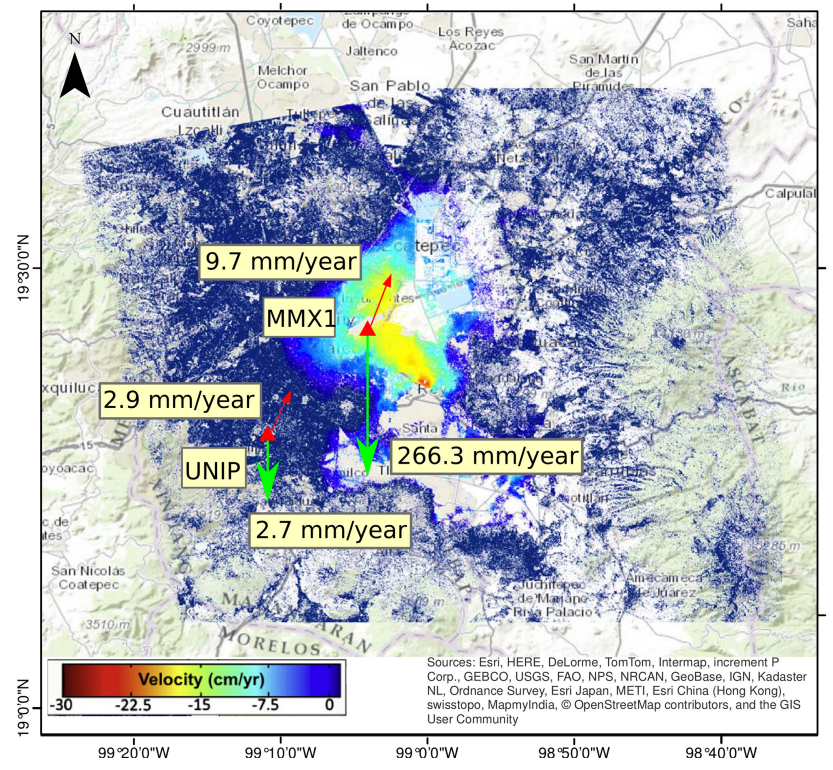

Figure 7. Horizontal (red) and vertical (green) velocity vectors at MMX1 and UNIP with respect to the local reference fame (SGOMRF). The color patterns represent the average subsidence rate derived from InSAR analysis (Chaussard et al., 2014). The three-component positional time series of UNIP and MMXI are plotted in Fig. 10.

proposed the detaching of the South Louisiana Allochthon which contributed to both the southward motion and subsidence in this area. Latter studies, however, suggested the major driving mechanism of subsidence in this area is the 

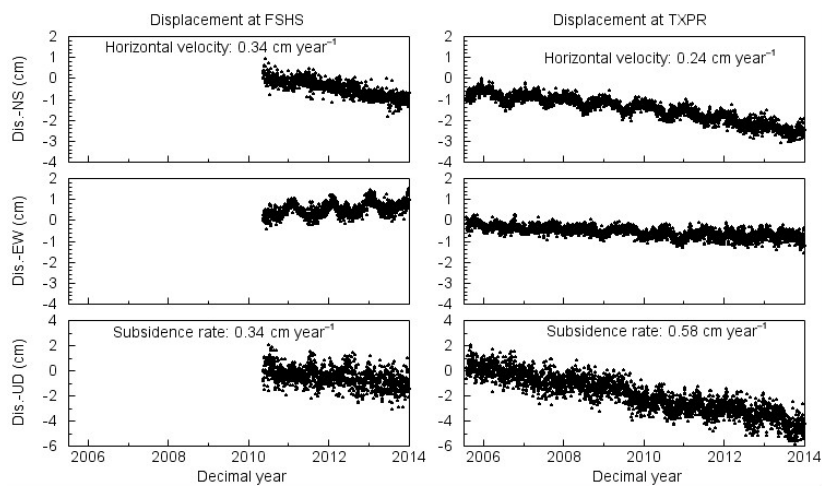

Figure 8. Three-component displacement time series from two CGPS sites with considerable horizontal movements. FSHS is located at Franklin, Louisiana (Fig. 9a). TXPR is located at Pharr, Texas (Fig. 4). The reference frame is SGOMRF.

compaction of shallow strata with minor or no contribution from active faulting and deep crustal processes (Blum et al., 2008; Edrington et al., 2008; Törnqvist et al., 2008; Wolstencroft et al., 2014; Yu et al., 2012). Our data show a lower rate of southward displacement, which may indicate that the horizontal motion is mainly caused by differential compaction and minor contribution from downslope movement of listric faults. The large horizontal velocity at FSHS may be a sitespecific feature related to the obvious seasonal motion in the EW component. TXPR, a permanent GPS site (2005-2014) located at Pharr, Texas, has a horizontal southwest movement of $2.4 \mathrm{~mm} \mathrm{yr}^{-1}$ (Fig. 8). The antenna pole is anchored on a wall of an office building owned by the Texas Department of Transportation. GPS observations also show steady subsidence $\left(5.8 \mathrm{~mm} \mathrm{yr}^{-1}\right)$ at this site. The horizontal movement could be associated with local subsidence. Further study is needed to verify the cause of the horizontal motion.

\section{Vertical ground deformation}

The overall spatial variation of vertical velocities in the GOM region is much greater compared to that of horizontal velocities. There are certain stations showing extremely large downward vertical velocities in this region. Figure $4 \mathrm{~b}$ indicates four rapid subsidence zones in the GOM region - the southeastern Louisiana area, the Houston metropolitan area, Aguascalientes, and Mexico City. The drivers of subsidence vary from place to place. Different drivers would result in different subsidence patterns - the spatial and temporal variability of subsidence rates. In this section, we discuss subsidence in southeastern Louisiana, Houston, Aguascalientes and Mexico City.

\subsection{Subsidence in the southeastern Louisiana}

The causes behind present subsidence in southeastern Louisiana have been controversial and heavily studied. Ram- sey and Moslow (1987) attributed $80 \%$ of the present subsidence on the coast of Louisiana to "compactional subsidence". Roberts et al. (1994) studied relationships between subsidence rates and faulting, land loss, thickness and characteristics of Holocene sediment in the Louisiana coastal area, and they concluded that sediment compaction was a primary cause of subsidence. A number of studies proposed that the present-day subsidence in the Mississippi Delta is mostly caused by the isostatic response to the delta load (e.g., Ivins et al., 2007; Jurkowski et al., 1984). However, Dokka (2006) argued the conventional opinions; using a case study conducted in the Michoud area of Orleans Parish, Louisiana, Dokka (2006) concluded that $73 \%$ $\left(16.9 \mathrm{~mm} \mathrm{yr}^{-1}\right)$ of subsidence during the period 1969-1971 and $50 \%\left(7.1 \mathrm{~mm} \mathrm{yr}^{-1}\right)$ of subsidence during the period 1971-1977 was attributed to tectonism (fault movements). Dokka and his colleagues further addressed tectonic-induced subsidence in their other publications (Dixon et al., 2006; Dokka, 2011; Dokka et al., 2006). Wolstencroft et al. (2014) investigated the cause of subsidence in the Mississippi Delta through geophysical modeling and concluded that presentday basement subsidence rate due to sediment loading was less than $\sim 0.5 \mathrm{~mm} \mathrm{yr}^{-1}$ and the glacial isostatic adjustment was likely to be the major driver of deep-seated subsidence.

Figure 9a and c illustrate the velocity vectors and positional time series at long-term GPS stations across the southeastern Louisiana area. Considerable subsidence rates are recorded at two near-coast stations: LMCN (foundation depth $36.5 \mathrm{~m}$ ) and GRIS (foundation depth unknown) $(<10 \mathrm{~km}$ to the coastline). Both sites indicate steady subsidence of approximately $6 \mathrm{~mm} \mathrm{yr}^{-1}$ over 10 years. Four inland stations FSHS (foundation depth $>5 \mathrm{~m}$ ), AWES (foundation depth $1 \mathrm{~m}$ ), HOUM (foundation depth $>15 \mathrm{~m}$ ) and DSTR (foundation depth unknown) show smaller subsidence rates $\left(2-4 \mathrm{~mm} \mathrm{yr}^{-1}\right)$. The seaward increase in the rate of subsidence may be a combined result of shallow sediment compaction and deep basement subsidence. Wolstencroft et al. (2014) demonstrated that present-day Pleistocene basement subsidence (deep subsidence) in the Mississippi Delta produced by viscoelastic deformation mechanisms increased seaward. The natural compaction of young sediments could occur in new infill and recently drained mashes (Törnqvist et al., 2008). GPS stations underlain by shallow (Holocene) sediments in this area will be subject to the ongoing compaction. Most data used in this study are from buildingbased stations. Therefore the monuments of GPS stations are building foundations which are typically $5-15 \mathrm{~m}$ below the land surface. In this case, the contribution from the uppermost Holocene compaction is minimum and our subsidence rate estimates should be considered minimum estimates. The foundation depth used in this study is collected from Dokka et al. (2006) and GPS $\log$ files from NGS. Unfortunately, this information is not always available in the GPS log files. The foundation depth of a GPS site directly determines its measuring target; therefore, it is of great importance to check this 


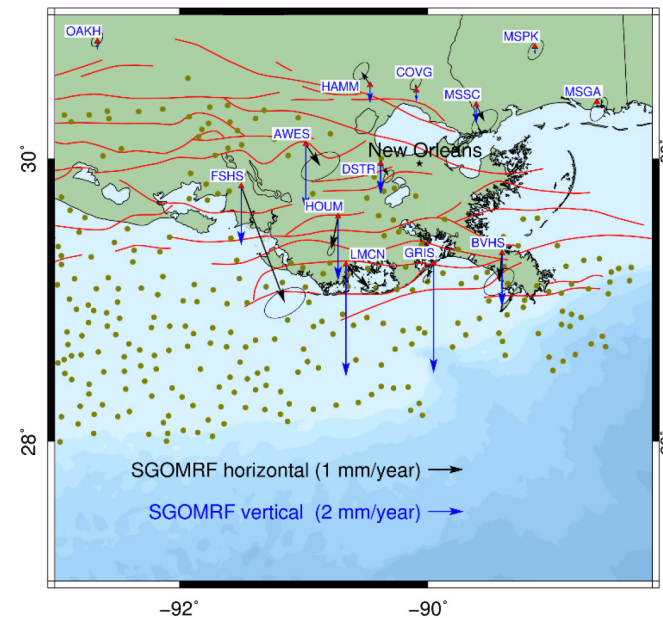

(a)

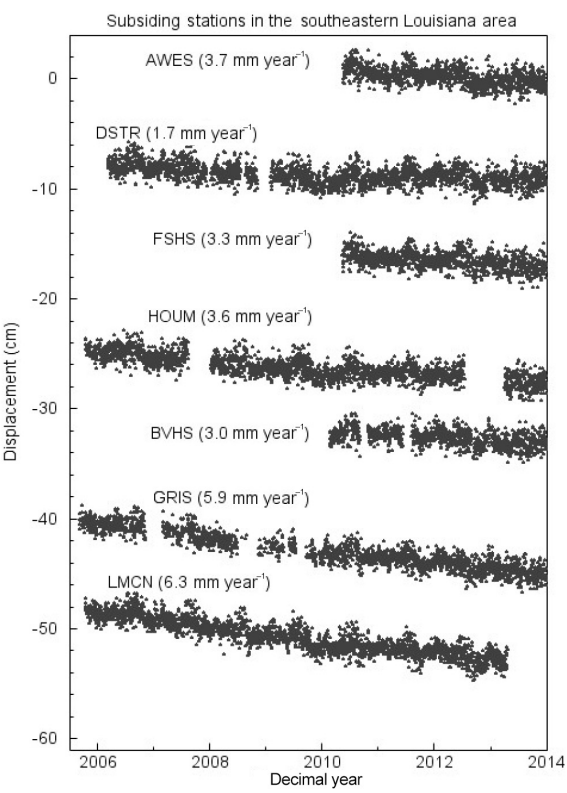

(c)

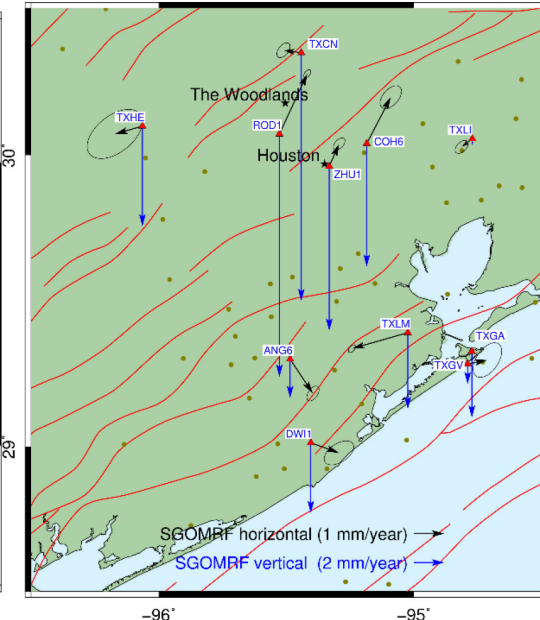

(b)

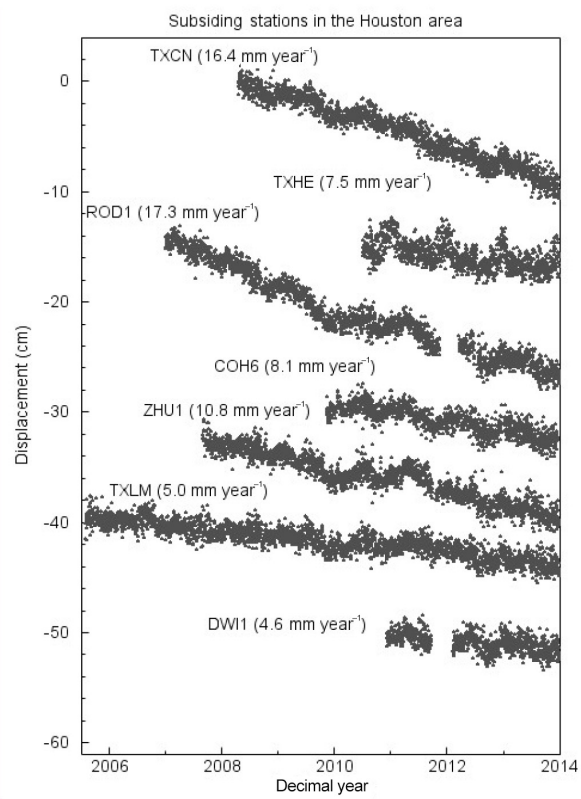

(d)

Figure 9. Top maps show vertical and horizontal velocity vectors in (a) southeastern Louisiana and (b) Houston. Bottom plots show vertical positional time series of subsiding stations in (c) southeastern Louisiana $\left(>1.5 \mathrm{~mm} \mathrm{yr}^{-1}\right)$ and (d) Houston-Galveston $(>4.5 \mathrm{~mm} \mathrm{yr}-1)$. The reference frame is SGOMRF.

information while interpreting the data. And we hope more GPS network maintainers will include this information in the $\log$ files.

Compared to near-coast sites LMCN (2005-2014) and GRIS (2005-2014), another near-coast GPS site BVHS (2002-2014) (foundation depth $>20 \mathrm{~m}$ ) recorded a $50 \%$ smaller subsidence rate $\left(3 \mathrm{~mm} \mathrm{yr}^{-1}\right)$. This rate is comparable to the rate $\left(3.5 \mathrm{~mm} \mathrm{yr}^{-1}\right)$ reported by Dokka et al. (2006) and substantially smaller than the rate $\left(5.7 \mathrm{~mm} \mathrm{yr}^{-1}\right)$ reported by Karegar et al. (2015). Note that, due to antenna changes and two large gaps (13 months and 8 months), the data prior to 2010 were not used to calculate the subsidence rate at
BVHS. The choice of record length may explain the large difference with the rate reported by Karegar et al. (2015) in which the full data span is used. The reason for the smaller subsidence rate at BVHS compared to LMCN and GRIS is unclear. Morton and Bernier (2010) showed historical subsidence rates calculated from repeat leveling surveys at benchmarks along state highway LA23 between Chalmette and Venice (near the location of BVHS), state highway LA1 between Raceland and Grand Isle (near the location of GRIS), and state highway LA 56 between Houma and Cocodrie (near the location of LMCN). The 1965/1966 to 1993 average subsidence rates along LA1 and LA56 was 
9.6 and $11 \mathrm{~mm} \mathrm{yr}^{-1}$, respectively, whereas, the subsidence rates along LA23 near the location of BVHS was much larger with greater than $25 \mathrm{~mm} \mathrm{yr}^{-1}$ between 1964 and 1971 and decreased to about $18 \mathrm{~mm} \mathrm{yr}^{-1}$ between 1971 to 1984 . The leveling lines encompass a much larger area compared to the spot measurements by GPS stations. Therefore, the subsidence rate measured at the single spot BVHS may not be able to represent the subsidence rate in a larger area.

Despite the different subsidence rates between coastal sites and inland sites, the overall spatial variation of subsidence rates across southeastern Louisiana is relatively smaller compared to that of the Houston metropolitan area. The slight variation of subsidence rates in space and the steady subsidence in time suggest that the subsidence in southeastern Louisiana is not likely dominated by the compaction of shallow aquifers associated with groundwater pumping. Groundwater pumping induced subsidence often shows considerable spatial and/or temporal variations as illustrated by subsidence in the metropolitan area of Houston and Mexico City (discussed in the following sections). In southeast Louisiana, groundwater withdrawal is minimal because groundwater quality is affected by saltwater encroachment (Baumann et al., 2006; Meckel, 2008). The exception is for the greater New Orleans area, where groundwater is pumped from shallow upper Pleistocene aquifers. Spatial correlations between areas of large subsidence and areas with high-yield groundwater wells in the New Orleans area were reported by Dokka (2011).

Hydrocarbon production has been frequently discussed as one of the possible drivers for subsidence in southeastern Louisiana (Chang et al., 2014; Kolker et al., 2011; Meckel, 2008). The oil production in this region peaked at $\sim 446$ million barrels in 1968 but has decreased consistently to less than $\sim 55$ million barrels after 2005 (Kolker et al., 2011; Meckel, 2008). The data used in this study are mostly from 2005, therefore we consider the possible contribution from hydrocarbon production to the subsidence observed in our data is marginal.

\subsection{Subsidence in the Houston area}

The groundwater induced subsidence in the Houston area has been intensively investigated by researchers from the US Geological Survey (USGS) (Bawden et al., 2012; Galloway et al., 1999; Johnson et al., 2011; Kasmarek et al., 2009, 2010, 2012, 2013), National Geodetic Survey (NGS) (Zilkoski et al., 2003), and local research institutions (e.g., Engelkemeir et al., 2010; Kearns et al., 2015; Khan et al., 2014; Qu et al., 2015; Wang and Soler, 2013; Wang et al., 2015b). A recent study conducted by Yu et al. (2014) indicated that the subsidence in the Houston metropolitan area is attributed by the compaction of aquifers within about $500 \mathrm{~m}$ to the ground surface. Since groundwater usage changes according to the local population and land usage, the subsidence resulting from groundwater withdrawal will vary in space. The subsidence rate will also change over time in accordance to the city development and policy changes. Historically, subsidence in the Houston area had been primarily occurring in the eastern and southeastern portions. A comparison of the current subsidence and recent subsidence (1915-2001) mapped by the USGS (Bawden et al., 2012) indicates that the subsidence in the Houston area has been migrating to the western and northern areas since the 1990s. The overall subsidence has also been reduced significantly as a result of rigidly enforced groundwater regulation plans (Harris-Galveston Subsidence District, 2013).

Figure $9 \mathrm{~b}$ and $\mathrm{d}$ illustrate the velocity vectors and positional time series at long-term GPS stations within the Houston area. The spatial variation of subsidence in the Houston area is more significant than that in southeastern Louisiana. The highest subsidence rates in the Houston area are recorded at two inland sites: TXCN and ROD1 (Table 3). These two stations are more than $100 \mathrm{~km}$ away from the coastline. The subsidence rate is as high as $17 \mathrm{~mm} \mathrm{yr}^{-1}$ at TXCN. Two coastal stations TXGV and TXGA record subsidence rates of only 1.3 and $4.4 \mathrm{~mm} \mathrm{yr}^{-1}$, respectively. Considerable temporal variations in subsidence rates are also identified at several sites. For instance, the subsidence rate at ROD1 was $25 \mathrm{~mm} \mathrm{yr}^{-1}$ before 2010 and has reduced to $13 \mathrm{~mm} \mathrm{yr}^{-1}$ after 2010 due to the enforced groundwater regulation since 2010 (Fig. 5) (Harris-Galveston Subsidence District, 2013).

\subsection{Salt tectonics}

The Gulf Coast area is one of the world's largest salt dome regions. Over 500 salt domes have been discovered onshore and under the sea floor of the GOM (Beckman and Williamson, 1990). Long-term accumulation of the salt movements could exert an impact on surface morphological features and cause fault growth. The vertical velocity vectors illustrated in this study do not show any considerable vertical movement that can be resulted from salt dome uplift. Jackson and Seni (1983) showed that the maximum net growth rate of diapirs in East Texas is 150 to $230 \mathrm{~m}$ per million years, which equals $\sim 0.2 \mathrm{~mm} \mathrm{yr}^{-1}$. The ground deformation rate at this level is below the limit that can be identified with the current GPS geodesy infrastructure in this region.

\subsection{Subsidence in central Mexico}

The CGPS sites in two central Mexico cities - Aguascalientes and Mexico City show extremely rapid subsidence. The causality between groundwater extraction and land subsidence in Mexico City was first investigated in the 1930s and then the 1940s (Carrillo, 1947; Cuevas, 1936). Groundwater accounts for nearly half of Mexico City's water usage (Sosa-Rodriguez, 2010). As of 2011, shallow aquifers in this region had been seriously overexploited (Engel et al., 2011). The ground water level has been declining at aver- 
Table 3. Horizontal $\left(V_{\mathrm{h}}\right)$ and vertical velocities $\left(V_{\mathrm{v}}\right)$ of GPS stations plotted in Fig. 9.

\begin{tabular}{lcrrlccc}
\hline \multicolumn{2}{c}{$\begin{array}{c}\text { Houston } \\
\text { Reference frame: SGOMRF }\end{array}$} & & \multicolumn{2}{c}{$\begin{array}{c}\text { Southeastern Louisiana } \\
\text { Reference frame: SGOMRF }\end{array}$} \\
\cline { 1 - 2 } \cline { 6 - 7 } Station & $\begin{array}{c}V_{\mathrm{h}} \\
\left(\mathrm{mm} \mathrm{yr}^{-1}\right)\end{array}$ & $\begin{array}{r}V_{\mathrm{V}} \\
\left(\mathrm{mm} \mathrm{yr}^{-1}\right)\end{array}$ & & & Station & $\begin{array}{c}V_{\mathrm{h}} \\
\left(\mathrm{mm} \mathrm{yr}^{-1}\right)\end{array}$ & $\begin{array}{c}V_{\mathrm{v}} \\
\left(\mathrm{mm} \mathrm{yr}^{-1}\right)\end{array}$ \\
\hline ROD1 & 2.33 & -17.32 & & LMCN & 0.94 & -6.30 \\
TXCN & 0.56 & -16.38 & & GRIS & 0.46 & -5.93 \\
ZHU1 & 0.80 & -10.80 & & AWES & 0.74 & -3.76 \\
COH6 & 1.72 & -8.10 & & HOUM & 0.96 & -3.62 \\
TXHE & 0.94 & -7.51 & & FSHS & 3.49 & -3.33 \\
TXLM & 1.90 & -5.03 & & BVHS & 0.82 & -3.02 \\
DWI1 & 0.98 & -4.63 & & DSTR & 0.42 & -1.74 \\
TXGA & 0.12 & -4.36 & & & & \\
ANG6 & 1.35 & -2.57 & & & & \\
TXGV & 0.66 & -1.34 & & & & \\
TXLI & 0.44 & -0.44 & &
\end{tabular}

age rates ranging from 0.1 to $1.5 \mathrm{~m} \mathrm{yr}^{-1}$ in different zones since 1983 (Joint Academies Committee on the Mexico City Water Supply et al., 1995). Figure 10 illustrates the threecomponent positional time series at three CGPS sites: INEG, MMX1, and UNIP. INEG is located in the city of Aguascalientes, Mexico. This station shows a steady subsidence rate of $25.7 \mathrm{~mm} \mathrm{yr}^{-1}$. MMX1 records steady land subsidence at a rate of $266.3 \mathrm{~mm} \mathrm{yr}^{-1}$, which could be the most rapid subsidence rate ever recorded by a CGPS station. The subsidence rate at the center of the subsidence bowl could be even larger. In fact, a subsidence rate as high as $370 \mathrm{~mm} \mathrm{yr}^{-1}$ (1996-2005) was derived from InSAR studies in Mexico City (Cabral-Cano et al., 2008). UNIP records a small subsidence rate of $2.7 \mathrm{~mm} \mathrm{yr}^{-1}$. The distance between MMX1 and UNIP is only about $17.8 \mathrm{~km}$. The subsidence rate at MMX1 is about 100 times higher than that at UNIP. It demonstrates the significant spatial variation of the subsidence rate in Mexico City.

\section{Conclusions}

This study utilizes the current GPS geodesy infrastructure in the GOM region to investigate the ground deformation associated with subsidence and faulting. A sophisticated regional GPS geodesy infrastructure should include three components: individual GPS stations, a stable local reference frame, and sophisticated positioning software packages. Currently, a unified "local reference frame" does not exist in the GOM region. This study established a stable local reference frame (SGOMRF) to fill the gap. In the first release of the SGOMRF, the 14 Helmert transformation parameters for converting coordinates from the IGS08 to SGOMRF are provided (Table 1). The SGOMRF will be incrementally improved and periodically updated to synchronize with the updates of the IGS reference frame. The potential applica-
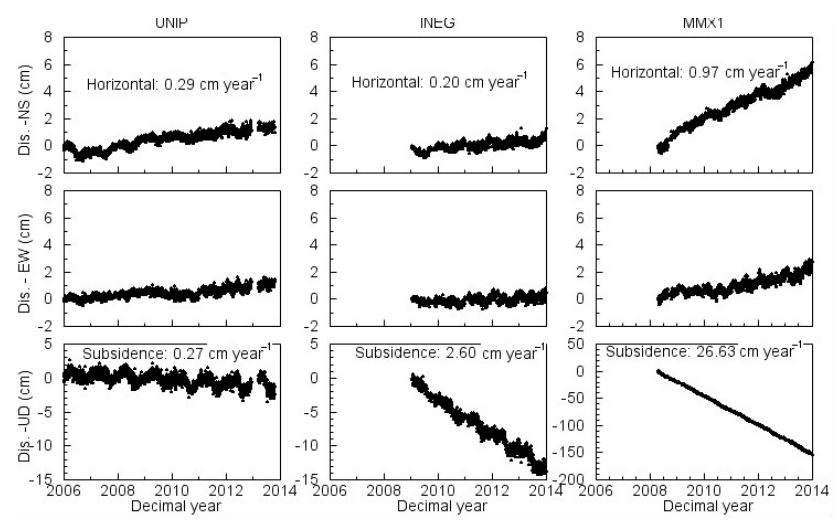

Figure 10. Three-component displacement time series of three CGPS stations in central Mexico. The reference frame is SGOMRF. The locations of UNIP and MMX1 are marked in Fig. 7 and the location of INEG is marked in Fig. 4.

tions of the local reference frame include providing a consistent framework for precisely monitoring coastal hazards over space and time, studying long-term coastal erosion and wetland loss, studying sea level rise, and comparing research results from different research groups. The stable reference frame will also be useful for long-term health monitoring of dams, sea walls, high-rise buildings, long-span bridges and for planning and designing coastal restoration projects.

GPS observations show significant land subsidence in the coastal area of southeastern Louisiana, the Houston metropolitan area, Aguascalientes, and Mexico City. Significant spatial variations of subsidence rates due to differences in groundwater withdraw and clay layer thickness are observed in the Houston area and Mexico City. The decrease of the subsidence rate over time is also observed at GPS stations located in Houston. The GPS sites in the southeastern Louisiana area show steady subsidence and a general south- 
ward horizontal movement toward the GOM. This may suggest a deep tectonic process associated with faulting. Subsidence resulting from faulting would be difficult to stop through human efforts. As a result, the smaller but steady subsidence (4-6 $\mathrm{mm} \mathrm{yr}^{-1}$ ) would cause considerable damage to the coastal protection infrastructure (e.g., sea walls, levees, flood walls, storm surge barriers) in the long term.
GPS observations presented in this study do not show any considerable ground movements that could be associated with salt tectonics or faults. The magnitude of salt dome uplift and faulting may be below the level that can be identified by the current GPS geodesy infrastructure with a time span less than a decade. A denser CGPS network and a longer period of data accumulation are crucial for a more comprehensive study of local ground deformation within the GOM region. 
Appendix A: The GPS velocities with respect to SGOMRF

Table A1. Locations and velocities of 148 GPS stations within the Gulf of Mexico region with respect to SGOMRF.

\begin{tabular}{|c|c|c|c|c|c|c|c|c|}
\hline $\begin{array}{l}\text { Station } \\
\text { name }\end{array}$ & $\begin{array}{r}\text { Lat } \\
(\mathrm{deg})\end{array}$ & $\begin{array}{l}\text { Long } \\
\text { (deg) }\end{array}$ & $\begin{array}{r}\text { Height } \\
(\mathrm{m})\end{array}$ & Date begin & Date end & $\begin{array}{r}V_{\text {east }} \\
\left(\mathrm{mm} \mathrm{yr}^{-1}\right)\end{array}$ & $\begin{array}{r}V_{\text {north }} \\
\left(\mathrm{mm} \mathrm{yr}^{-1}\right)\end{array}$ & $\begin{array}{r}V_{\mathrm{up}} \\
\left(\mathrm{mm} \mathrm{yr}^{-1}\right)\end{array}$ \\
\hline $1 \mathrm{NSU}$ & 31.7508 & 266.9024 & 28.05849 & 16 Jan 2004 & 30 May 2014 & 0.18 & 0.32 & -1.81 \\
\hline $1 \mathrm{ULM}$ & 32.529 & 267.9241 & 15.97499 & 14 Jun 2003 & 30 May 2014 & 0.52 & -0.29 & -2.71 \\
\hline AL40 & 32.9627 & 273.9937 & 210.9113 & 1 Jan 2007 & 10 Oct 2012 & -0.19 & -0.01 & -0.32 \\
\hline AL70 & 31.7827 & 274.0348 & 141.9044 & 6 Aug 2006 & 5 Nov 2013 & -0.01 & 0.13 & -1.32 \\
\hline ALDI & 30.2492 & 271.922 & -19.2058 & 28 Мау 2009 & 30 May 2014 & 0.45 & -0.86 & -1.41 \\
\hline ANG6 & 29.3016 & 264.5151 & -9.18868 & 16 Nov 2007 & 30 May 2014 & 0.75 & -1.13 & -2.57 \\
\hline ARCM & 33.5424 & 267.1173 & 25.46923 & 9 Aug 2005 & 30 May 2014 & -0.15 & 0.41 & -1.52 \\
\hline ARHP & 33.6961 & 266.3994 & 84.46747 & 9 Aug 2005 & 30 May 2014 & 0.07 & -0.15 & 1.15 \\
\hline AWES & 30.1003 & 269.017 & -10.3151 & 16 May 2010 & 30 May 2014 & 0.41 & -0.62 & -3.76 \\
\hline BKVL & 28.4738 & 277.5463 & -6.56392 & 13 Aug 2003 & 30 May 2014 & 0.20 & -0.06 & 1.12 \\
\hline BNFY & 30.8484 & 274.3962 & -0.62191 & 18 May 2005 & 30 May 2014 & 0.17 & -0.11 & -0.43 \\
\hline BVHS & 29.3368 & 270.5936 & -15.7407 & 21 Aug 2002 & 30 May 2014 & -0.09 & -0.82 & -3.02 \\
\hline CCV5 & 28.4602 & 279.4548 & -24.235 & 24 Jan 2007 & 30 May 2014 & -0.45 & -0.27 & 0.80 \\
\hline CCV6 & 28.46 & 279.4545 & -24.2346 & 24 Jan 2007 & 30 May 2014 & 0.12 & 0.00 & -1.20 \\
\hline CHME & 35.2767 & 279.1109 & 225.2528 & 12 Feb 2002 & 9 Feb 2012 & -0.24 & 0.24 & -0.97 \\
\hline COH6 & 30.0397 & 264.8152 & -10.2856 & 1 Jan 2009 & 30 May 2014 & 0.79 & 1.52 & -8.10 \\
\hline COVG & 30.4759 & 269.9045 & -5.94049 & 17 Jul 2004 & 30 May 2014 & -0.02 & 0.20 & -0.63 \\
\hline CRST & 30.7261 & 273.4938 & 32.56775 & 26 Jul 2005 & 30 May 2014 & -0.21 & -0.54 & -0.12 \\
\hline DLND & 29.0564 & 278.7368 & -1.27001 & 14 Jan 2005 & 30 May 2014 & 0.12 & 0.01 & -0.26 \\
\hline DSTR & 29.9646 & 269.6178 & -20.0388 & 8 Mar 2006 & 30 May 2014 & 0.23 & -0.35 & -1.74 \\
\hline DUNN & 29.0622 & 277.6291 & -7.84893 & 25 Feb 2004 & 30 May 2014 & -0.38 & -0.04 & 1.54 \\
\hline DWI1 & 29.0136 & 264.5963 & -20.0373 & 22 May 2009 & 30 May 2014 & 0.92 & -0.33 & -4.63 \\
\hline EXU0 & 23.564 & 284.1266 & -20.0577 & 29 Jun 2007 & 30 May 2014 & 0.60 & 0.33 & 0.07 \\
\hline FSHS & 29.8053 & 268.4978 & -15.8687 & 13 May 2010 & 30 May 2014 & 1.22 & -3.27 & -3.33 \\
\hline GABR & 34.8644 & 275.6729 & 515.5019 & 1 Jun 2005 & 30 May 2014 & 0.28 & -0.10 & -0.21 \\
\hline GACC & 33.5458 & 277.8662 & 98.50342 & 7 Nov 2003 & 30 May 2014 & -0.34 & 0.54 & 0.76 \\
\hline GAGR & 33.2278 & 275.7221 & 264.0847 & 9 Mar 2005 & 15 Sep 2013 & -0.02 & 0.03 & 0.30 \\
\hline GANW & 33.3058 & 275.2326 & 260.0124 & 8 Mar 2005 & 30 May 2014 & 0.24 & -0.08 & -0.09 \\
\hline GRIS & 29.2655 & 270.0427 & -17.0403 & 3 Sep 2005 & 30 May 2014 & -0.20 & -0.44 & -6.18 \\
\hline HAC6 & 34.2808 & 272.1441 & 252.4308 & 17 Nov 2007 & 30 May 2014 & -0.54 & 0.62 & 0.71 \\
\hline HAMM & 30.5131 & 269.5324 & 5.818601 & 13 Feb 2001 & 30 May 2014 & -0.25 & 0.39 & -1.04 \\
\hline HOUM & 29.5923 & 269.2764 & -12.7243 & 22 Nov 2003 & 30 May 2014 & -0.20 & -0.94 & -3.62 \\
\hline INEG & 21.8562 & 257.7158 & 1887.762 & 21 Jul 1999 & 30 May 2014 & 0.77 & 1.72 & -25.77 \\
\hline JCT1 & 30.4794 & 260.1989 & 571.8231 & 25 Oct 2005 & 12 Apr 2014 & -0.14 & 0.14 & 0.78 \\
\hline JTNT & 33.0172 & 259.0229 & 684.5088 & 22 Маy 1997 & 22 Dec 2009 & -0.12 & 0.66 & -2.37 \\
\hline JXVL & 30.484 & 278.2985 & -19.2207 & 21 May 2002 & 30 May 2014 & -0.18 & -0.30 & -1.13 \\
\hline KNS5 & 33.482 & 280.657 & -20.266 & 7 Nov 2007 & 30 May 2014 & 0.10 & -0.37 & -1.23 \\
\hline KVTX & 27.546 & 262.1071 & -2.61039 & 20 Mar 2007 & 30 May 2014 & -0.67 & -0.12 & -2.05 \\
\hline KWST & 24.5537 & 278.2457 & -11.8004 & 7 Dec 2002 & 15 Sep 2013 & 0.42 & 0.44 & -0.82 \\
\hline KYW5 & 24.5823 & 278.347 & -13.6279 & 11 Oct 2007 & 30 May 2014 & 0.42 & 0.09 & 1.11 \\
\hline KYW6 & 24.5823 & 278.3472 & -13.6613 & 11 Oct 2007 & 30 May 2014 & 0.10 & -0.02 & 2.43 \\
\hline LAUD & 26.1962 & 279.8269 & -19.7442 & 12 Apr 2005 & 30 May 2014 & -0.19 & -0.14 & -1.77 \\
\hline LMCN & 29.255 & 269.3387 & -16.1493 & 23 Apr 2003 & 30 May 2014 & 0.66 & -0.67 & -6.30 \\
\hline LSUA & 31.1788 & 267.5877 & 4.702045 & 21 Aug 2003 & 30 May 2014 & -0.07 & 0.25 & -0.07 \\
\hline MCD5 & 27.8498 & 277.4677 & -15.7006 & 23 Feb 2007 & 30 May 2014 & 0.34 & -0.32 & -0.21 \\
\hline MCN5 & 32.6953 & 276.4394 & 60.49587 & 2 Nov 2007 & 30 May 2014 & -0.12 & -0.04 & -0.09 \\
\hline MCN6 & 32.6954 & 276.4397 & 60.81582 & 2 Nov 2007 & 30 May 2014 & -0.22 & 0.21 & -1.59 \\
\hline MERI & 20.98 & 270.3797 & 7.852101 & 1 Mar 2003 & 30 May 2014 & 0.49 & 0.64 & -0.38 \\
\hline MLF6 & 32.0905 & 272.6078 & 29.37245 & 13 Jun 2007 & 30 May 2014 & -0.04 & 0.12 & -0.35 \\
\hline MMD1 & 20.9319 & 270.3372 & 28.67041 & 26 Apr 2008 & 30 May 2014 & 0.76 & -0.24 & -0.77 \\
\hline MMX1 & 19.4317 & 260.9316 & 2235.241 & 26 Apr 2008 & 30 May 2014 & 3.47 & 9.01 & -265.93 \\
\hline
\end{tabular}


Table A1. Continued.

\begin{tabular}{|c|c|c|c|c|c|c|c|c|}
\hline $\begin{array}{l}\text { Station } \\
\text { name }\end{array}$ & $\begin{array}{r}\text { Lat } \\
(\mathrm{deg})\end{array}$ & $\begin{array}{l}\text { Long } \\
\text { (deg) }\end{array}$ & $\begin{array}{l}\text { Height } \\
(\mathrm{m})\end{array}$ & Date begin & Date end & $\begin{array}{r}V_{\text {east }} \\
\left(\mathrm{mm} \mathrm{yr}^{-1}\right)\end{array}$ & $\begin{array}{r}V_{\text {north }} \\
\left(\mathrm{mm} \mathrm{yr}^{-1}\right)\end{array}$ & $\begin{array}{r}V_{\text {up }} \\
\left(\mathrm{mm} \mathrm{yr}^{-1}\right)\end{array}$ \\
\hline MSB5 & 34.1145 & 269.3097 & 24.21282 & 25 Sep 2007 & 30 May 2014 & -0.46 & 0.24 & 0.24 \\
\hline MSCL & 3.7467 & 269.2669 & 34.03477 & 18 Aug 2006 & 30 May 2014 & -0.15 & 0.48 & -0.08 \\
\hline MSGA & 30.3946 & 271.3549 & -9.27407 & 16 Dec 2007 & 30 May 2014 & 0.06 & -0.20 & -0.33 \\
\hline MSPK & 30.7791 & 270.8567 & 22.94471 & 7 Mar 2008 & 30 May 2014 & 0.02 & -0.09 & -0.45 \\
\hline MSSC & 30.3752 & 270.3861 & -13.0918 & 1 May 2005 & 30 May 2014 & 0.24 & -0.48 & -1.08 \\
\hline MTNT & 25.8658 & 279.093 & -20.5447 & 3 Jul 2003 & 30 May 2014 & -0.03 & 0.45 & -0.08 \\
\hline NAPL & 26.1486 & 278.2237 & -19.0546 & 3 Jul 2003 & 30 May 2014 & 0.32 & 0.38 & -0.84 \\
\hline NASO & 25.0525 & 282.5377 & -21.2536 & 26 Jun 2007 & 30 May 2014 & 1.34 & 0.20 & -0.32 \\
\hline NBR5 & 35.1752 & 282.95 & -24.6756 & 21 Mar 2007 & 30 May 2014 & 0.76 & -0.66 & -0.44 \\
\hline NBR6 & 35.175 & 282.9502 & -24.9041 & 21 Mar 2007 & 30 May 2014 & 0.11 & -0.59 & -0.23 \\
\hline NC77 & 35.1226 & 279.0838 & 156.1923 & 8 May 2003 & 30 May 2014 & 0.19 & 0.14 & -0.87 \\
\hline NCAL & 35.3381 & 279.7865 & 111.2661 & 6 May 2004 & 30 May 2014 & 0.20 & 0.08 & 0.10 \\
\hline NCCA & 35.3417 & 280.6152 & 148.2418 & 18 May 2004 & 30 May 2014 & 0.04 & -0.04 & -0.58 \\
\hline $\mathrm{NCCO}$ & 35.3765 & 279.4358 & 153.021 & 24 Jul 2003 & 30 May 2014 & 0.28 & -0.52 & 0.01 \\
\hline NCKN & 34.9418 & 282.0195 & 14.1682 & $1 \mathrm{Jul} 2006$ & 30 May 2014 & -0.21 & -0.13 & 0.14 \\
\hline NCLI & 35.4202 & 281.1888 & 24.32739 & 6 May 2004 & 30 May 2014 & -0.19 & -0.72 & -0.52 \\
\hline NCLU & 34.6268 & 280.9223 & 14.42985 & 1 Jul 2006 & 30 May 2014 & -0.08 & -0.04 & -0.39 \\
\hline NCMR & 34.9819 & 279.4762 & 142.9632 & 8 May 2003 & 30 May 2014 & -0.18 & 0.49 & -1.45 \\
\hline NCSL & 33.9826 & 281.6099 & -11.4192 & 26 Feb 2008 & 30 May 2014 & -0.21 & -0.08 & -0.67 \\
\hline NCWH & 34.2804 & 281.2835 & -3.753 & 23 Dec 2007 & 30 May 2014 & 0.03 & -0.53 & -0.87 \\
\hline OAKH & 30.8155 & 267.343 & 20.22764 & 7 Apr 2004 & 30 May 2014 & -0.01 & 0.06 & -0.49 \\
\hline OKAD & 34.8003 & 263.2617 & 292.1217 & 3 Sep 2002 & 8 May 2014 & -0.34 & -0.21 & 0.90 \\
\hline OKAL & 34.6323 & 260.6706 & 400.4894 & 13 Jan 2005 & 30 May 2014 & -0.37 & 0.14 & 0.59 \\
\hline OKAO & 35.0764 & 261.7541 & 339.3266 & 11 Dec 2004 & 30 May 2014 & 0.31 & -0.07 & -0.27 \\
\hline OKCB & 27.266 & 279.1447 & -15.3341 & 7 Dec 2002 & 30 May 2014 & -0.08 & -0.04 & 0.09 \\
\hline OKCL & 35.4832 & 261.0285 & 469.5978 & 17 Dec 2002 & 30 May 2014 & -0.36 & 0.37 & 0.05 \\
\hline OKDN & 34.4793 & 262.0334 & 314.321 & 13 Jan 2005 & 30 May 2014 & 0.05 & 0.08 & -0.37 \\
\hline OKHV & 34.9132 & 265.3819 & 145.3273 & 6 Aug 2003 & 30 May 2014 & -0.35 & 0.23 & -0.41 \\
\hline OKLW & 34.5728 & 261.5901 & 313.5754 & 1 Sep 2002 & 30 May 2014 & 0.44 & -0.06 & 0.58 \\
\hline OKMA & 34.928 & 264.2628 & 200.812 & 19 Aug 2002 & 30 May 2014 & -0.26 & 0.83 & 0.00 \\
\hline OKTE & 35.2602 & 263.1022 & 301.9339 & 19 Aug 2002 & 30 May 2014 & -0.47 & -0.72 & 1.19 \\
\hline ORMD & 29.2982 & 278.8911 & -19.8807 & 3 Apr 2003 & 30 May 2014 & 0.19 & 0.09 & 0.35 \\
\hline PATT & 31.7783 & 264.2815 & 94.84571 & 23 Мay 1997 & 19 Oct 2009 & 0.00 & -0.19 & 0.26 \\
\hline $\mathrm{PBCH}$ & 26.8463 & 279.7807 & -16.8897 & 26 Feb 2005 & 30 May 2014 & 0.25 & -0.25 & 1.59 \\
\hline PCLA & 30.469 & 272.8106 & 1.945059 & 11 Feb 2004 & 30 May 2014 & 0.06 & -0.04 & -0.77 \\
\hline PLTK & 29.6634 & 278.3123 & -19.4786 & 21 May 2002 & 30 May 2014 & -0.08 & 0.20 & 0.60 \\
\hline PNCY & 30.2046 & 274.3218 & -18.6437 & 22 May 2002 & 17 Aug 2010 & -0.26 & -0.04 & 0.03 \\
\hline ROD1 & 30.0724 & 264.4732 & 17.71326 & 1 Jan 2007 & 30 May 2014 & 0.91 & 1.98 & -15.95 \\
\hline SA37 & 34.7241 & 273.3534 & 180.1435 & 24 Nov 2004 & 26 Sep 2012 & -0.60 & 0.43 & 0.38 \\
\hline SAL6 & 35.3673 & 265.1837 & 129.84 & 17 May 2007 & 30 May 2014 & 0.36 & 0.42 & -0.34 \\
\hline SAV5 & 32.1386 & 278.3037 & 8.584991 & 21 Oct 2007 & 30 May 2014 & -0.13 & -0.06 & -1.48 \\
\hline SCCC & 32.7829 & 280.062 & -11.3818 & 18 Mar 2005 & 9 Apr 2014 & -0.18 & -0.04 & -0.39 \\
\hline SCGP & 34.9377 & 277.7674 & 278.039 & 18 Mar 2005 & 30 Мау 2014 & -0.30 & 0.27 & -1.42 \\
\hline SCUB & 20.0121 & 284.2377 & 20.91134 & 6 Jan 2000 & 30 May 2014 & 3.26 & 0.15 & 0.79 \\
\hline SCWT & 32.9034 & 279.3316 & -3.38407 & 8 Feb 2006 & 30 May 2014 & 0.23 & -0.10 & -1.07 \\
\hline SG05 & 28.0652 & 279.3772 & -10.8197 & 5 Feb 2002 & 17 Dec 2013 & 0.32 & 0.08 & -0.09 \\
\hline SG34 & 35.2691 & 263.2598 & 275.8465 & 19 Jun 2003 & 30 Nov 2009 & -0.28 & -0.44 & 0.79 \\
\hline SHRV & 32.4277 & 266.2954 & 36.73838 & 18 Aug 2004 & 30 May 2014 & 0.27 & 0.37 & -0.73 \\
\hline SNFD & 35.4735 & 280.8419 & 94.08224 & 14 Apr 2002 & 30 May 2014 & -0.27 & -0.01 & -0.55 \\
\hline TXAB & 32.5033 & 260.2432 & 488.5989 & 2 Feb 2005 & 30 May 2014 & 0.27 & 0.25 & -0.08 \\
\hline TXAM & 35.1536 & 258.1215 & 1098.12 & 18 Jan 1996 & 30 May 2014 & -0.22 & 0.14 & 0.66 \\
\hline TXAU & 30.3117 & 262.2437 & 192.6338 & 18 Jan 1996 & 30 May 2014 & -0.14 & -0.01 & 0.58 \\
\hline TXBS & 30.1129 & 262.7094 & 140.0736 & 10 May 2004 & 30 May 2014 & 0.31 & -0.14 & 0.26 \\
\hline TXBU & 30.7505 & 261.8156 & 438.0251 & 10 May 2004 & 30 May 2014 & 0.12 & -0.06 & 0.13 \\
\hline
\end{tabular}


Table A1. Continued.

\begin{tabular}{|c|c|c|c|c|c|c|c|c|}
\hline $\begin{array}{l}\text { Station } \\
\text { name }\end{array}$ & $\begin{array}{r}\text { Lat } \\
(\mathrm{deg})\end{array}$ & $\begin{array}{l}\text { Long } \\
\text { (deg) }\end{array}$ & $\begin{array}{l}\text { Height } \\
\text { (m) }\end{array}$ & Date begin & Date end & $\begin{array}{r}V_{\text {east }} \\
\left(\mathrm{mm} \mathrm{yr}^{-1}\right)\end{array}$ & $\begin{array}{r}V_{\text {north }} \\
\left(\mathrm{mm} \mathrm{yr}^{-1}\right)\end{array}$ & $\begin{array}{r}V_{\mathrm{up}} \\
\left(\mathrm{mm} \mathrm{yr}^{-1}\right)\end{array}$ \\
\hline TXBW & 31.7376 & 261.0332 & 389.322 & 2 Feb 2005 & 12 Jul 2011 & -0.16 & 0.50 & -0.68 \\
\hline TXBY & 30.6858 & 263.6295 & 87.87761 & 2 Feb 2005 & 17 May 2012 & 0.43 & 0.53 & -1.98 \\
\hline $\mathrm{TXCH}$ & 34.4596 & 259.7217 & 563.9821 & 25 Jan 2005 & 30 May 2014 & 0.69 & -0.37 & 0.08 \\
\hline TXCN & 30.349 & 264.5588 & 48.81767 & $30 \mathrm{Jul} 2005$ & 30 May 2014 & -0.58 & 0.08 & -16.31 \\
\hline TXDE & 33.2105 & 262.8372 & 178.7829 & 29 Oct 2003 & 30 May 2014 & 0.04 & -0.23 & -1.61 \\
\hline TXDR & 29.3644 & 259.1005 & 280.1436 & $16 \mathrm{Jul} 2004$ & 30 May 2014 & 0.06 & -0.73 & -0.08 \\
\hline TXGA & 29.3279 & 265.2274 & -10.6737 & $30 \mathrm{Jul} 2005$ & 30 May 2014 & -0.01 & -0.12 & -4.36 \\
\hline TXGR & 32.2404 & 262.2456 & 177.4758 & 23 Sep 2005 & 30 May 2014 & 0.09 & -0.15 & -0.27 \\
\hline TXGV & 29.2851 & 265.2107 & -17.4398 & 16 Feb 2007 & $20 \mathrm{Jul} 2011$ & 0.65 & 0.13 & -1.34 \\
\hline TXHE & 30.099 & 263.9365 & 47.44116 & $30 \mathrm{Jul} 2005$ & 30 May 2014 & -0.91 & -0.26 & -6.59 \\
\hline TXJA & 33.1948 & 261.8544 & 326.0619 & 23 Sep 2005 & 30 May 2014 & -1.27 & 0.27 & 3.42 \\
\hline TXJC & 30.2665 & 261.6027 & 347.6093 & 10 May 2004 & 30 May 2014 & 0.31 & 0.17 & -0.13 \\
\hline TXKE & 32.4097 & 262.6768 & 227.9626 & 23 Sep 2005 & 30 Мay 2014 & 0.12 & 0.20 & -1.62 \\
\hline TXLF & 31.3564 & 265.2817 & 77.46693 & $30 \mathrm{Jul} 2005$ & 30 May 2014 & 0.16 & 0.00 & 0.43 \\
\hline TXLI & 30.0559 & 265.229 & -11.1035 & $30 \mathrm{Jul} 2005$ & 30 May 2014 & -0.35 & -0.27 & -0.44 \\
\hline TXLL & 30.7335 & 261.3214 & 306.3507 & $30 \mathrm{Jul} 2005$ & 30 May 2014 & -0.13 & 0.33 & -0.22 \\
\hline TXLM & 29.3922 & 264.9763 & -17.503 & $30 \mathrm{Jul} 2005$ & 30 Мay 2014 & -1.83 & -0.52 & -5.03 \\
\hline TXLR & 27.5139 & 260.5521 & 113.6236 & 28 Jan 2002 & 30 May 2014 & -0.26 & 0.26 & -0.12 \\
\hline TXLU & 33.5354 & 258.1572 & 956.0393 & 18 Jan 1996 & 30 May 2014 & 0.30 & -0.24 & -0.94 \\
\hline TXMA & 32.5353 & 265.7114 & 79.12099 & $30 \mathrm{Jul} 2005$ & 30 Мay 2014 & 0.03 & 0.83 & -0.79 \\
\hline TXNA & 32.0418 & 263.4613 & 105.4555 & 29 Oct 2003 & 30 May 2014 & -0.24 & 0.28 & 0.97 \\
\hline TXPA & 33.6742 & 264.443 & 145.0603 & $30 \mathrm{Jul} 2005$ & 30 May 2014 & -0.04 & 0.18 & -0.46 \\
\hline TXPR & 26.2085 & 261.8107 & 15.18814 & 28 Feb 2002 & 30 May 2014 & -0.73 & -2.33 & -5.52 \\
\hline TXPS & 28.8888 & 260.918 & 175.3575 & 13 Oct 2007 & 30 May 2014 & 0.12 & -1.04 & -3.85 \\
\hline TXPV & 28.6382 & 263.3815 & -16.5775 & 16 Apr 2010 & 30 May 2014 & 0.70 & -0.43 & -1.86 \\
\hline TXSG & 32.8557 & 262.6558 & 181.6959 & 23 Sep 2005 & 30 May 2014 & -0.53 & 0.06 & 0.09 \\
\hline TXSM & 29.8779 & 262.0973 & 157.3782 & 11 May 2004 & 30 May 2014 & -0.31 & 0.35 & 1.37 \\
\hline TXTY & 32.2496 & 264.6064 & 120.1438 & 30 Mar 2004 & 30 May 2014 & 0.09 & 0.25 & -1.45 \\
\hline TXWA & 31.5777 & 262.8895 & 101.7108 & 2 Feb 2005 & 30 May 2014 & 0.61 & -0.62 & -1.61 \\
\hline TXWE & 32.7589 & 262.1765 & 337.3788 & 23 Sep 2005 & 30 May 2014 & -0.29 & 0.35 & -0.05 \\
\hline TXWF & 33.8539 & 261.4944 & 280.1747 & 5 Aug 2003 & 30 May 2014 & -0.19 & 0.12 & 0.10 \\
\hline UNIP & 19.3127 & 260.8187 & 2308.24 & 9 Dec 2005 & 19 Oct 2013 & 1.26 & 2.62 & -2.66 \\
\hline UNPM & 20.8685 & 273.1318 & -0.46051 & 8 Aug 2007 & 30 May 2014 & 0.23 & -0.26 & -0.02 \\
\hline WACH & 27.5142 & 278.1176 & 9.157976 & 12 Apr 2005 & 30 May 2014 & -0.06 & 0.30 & -0.78 \\
\hline WNFL & 31.8972 & 267.2181 & 68.00915 & 24 May 1997 & 6 Aug 2010 & 0.09 & 0.19 & -2.03 \\
\hline XCTY & 29.631 & 276.8918 & -15.3071 & 11 Feb 2004 & 30 May 2014 & 0.47 & -0.10 & 1.40 \\
\hline ZEFR & 28.2276 & 277.8354 & -1.50876 & 3 Sep 2003 & 30 May 2014 & 0.05 & 0.16 & 1.08 \\
\hline ZFW1 & 32.8306 & 262.9335 & 155.1949 & 15 Jan 2003 & 30 May 2014 & 0.57 & -0.18 & 0.43 \\
\hline ZHU1 & 29.9619 & 264.6686 & 10.41867 & 15 Jan 2003 & 30 May 2014 & 0.32 & 0.73 & -10.80 \\
\hline ZJX1 & 30.6989 & 278.0918 & 1.69364 & 1 Jul 2002 & 30 May 2014 & 0.12 & -0.15 & 0.07 \\
\hline ZMA1 & 25.8246 & 279.6808 & -8.03093 & 11 Apr 2003 & 30 May 2014 & 0.12 & -0.01 & 0.14 \\
\hline ZME1 & 35.0674 & 270.0446 & 68.16135 & 13 Mar 2003 & 30 May 2014 & -0.10 & 0.02 & -0.24 \\
\hline ZTL4 & 33.3797 & 275.7033 & 260.6937 & 5 Nov 2002 & 30 May 2014 & -0.27 & -0.13 & -0.28 \\
\hline
\end{tabular}


Table A2. Locations and velocities of 13 reference stations used to establish SGOMRF.

\begin{tabular}{lrrrllrrr}
\hline $\begin{array}{l}\text { Station } \\
\text { name }\end{array}$ & $\begin{array}{r}\text { Lat } \\
(\mathrm{deg})\end{array}$ & $\begin{array}{r}\text { Long } \\
(\mathrm{deg})\end{array}$ & $\begin{array}{r}\text { Height } \\
(\mathrm{m})\end{array}$ & Date begin & Date end & $\begin{array}{r}V_{\text {east }} \\
\left(\mathrm{mm} \mathrm{yr}^{-1}\right)\end{array}$ & $\begin{array}{r}V_{\text {north }} \\
\left(\mathrm{mm} \mathrm{yr}^{-1}\right)\end{array}$ & $\begin{array}{r}V_{\text {up }} \\
\left(\mathrm{mm} \mathrm{yr}^{-1}\right)\end{array}$ \\
\hline AL20 & 34.71032 & -87.6627 & 131.8874 & 6 Aug 2006 & 30 May 2014 & 0.16 & -0.23 & 0.15 \\
ARLR & 34.67263 & -92.3826 & 73.18775 & 9 Aug 2005 & 30 May 2014 & -0.02 & 0.04 & -0.25 \\
GAMC & 32.70182 & -83.6486 & 91.35432 & 8 Mar 2005 & 5 Dec 2013 & 0.05 & 0.11 & -0.10 \\
GNVL & 29.687 & -82.277 & 22.43521 & 21 May 2002 & 30 May 2014 & 0.01 & -0.11 & 0.44 \\
MTY2 & 25.71551 & -100.313 & 521.7386 & 22 Sep 2005 & 30 May 2014 & 0.00 & 0.33 & 0.08 \\
OKAN & 34.1952 & -95.6214 & 140.2891 & 19 Aug 2002 & 17 Jun 2014 & -0.26 & 0.09 & -0.19 \\
OKAR & 34.16846 & -97.1693 & 235.7622 & 4 Dec 2004 & 30 May 2014 & -0.30 & -0.15 & -0.15 \\
RMND & 25.61378 & -80.3839 & -15.6992 & 3 Sep 2003 & 14 Jan 2014 & 0.10 & -0.07 & -0.17 \\
TAM1 & 22.27832 & -97.864 & 21.04278 & 9 Jan 2005 & 30 May 2014 & 0.23 & 0.15 & -0.36 \\
TXDC & 33.23622 & -97.6087 & 255.2784 & 23 Sep 2005 & 30 May 2014 & 0.34 & -0.14 & 0.19 \\
TXSA & 31.41432 & -100.473 & 566.0568 & 2 Aug 2003 & 30 May 2014 & -0.30 & 0.25 & -0.08 \\
TXSN & 30.15258 & -102.409 & 850.87 & 30 Jul 2005 & 30 May 2014 & 0.12 & -0.14 & 0.17 \\
TXST & 32.23259 & -98.1822 & 376.5754 & 23 Sep 2005 & 30 May 2014 & -0.18 & -0.17 & 0.09 \\
\hline
\end{tabular}


Acknowledgements. The authors thank NGS for providing GPS data to the public. Some data are provided by the UNAVCO Facility with support from the National Science Foundation (NSF) and National Aeronautics and Space Administration (NASA) under NSF Cooperative Agreement No. EAR-0735156. This study was supported by an NSF CAREER award EAR-1229278, an NSF MRI award EAR-1242383, and an NSF TUES award DUE-1243582.

Edited by: N. Kerle

Reviewed by: T. Törnqvist and two anonymous referees

\section{References}

Allis, R. G.: Review of subsidence at Wairakei field, New Zealand, Geothermics, 29, 455-478, doi:10.1016/S0375-6505(00)00016$\mathrm{X}, 2000$.

Bar-Sever, Y. E., Kroger, P. M., and Borjesson, J. A.: Estimating horizontal gradients of tropospheric path delay with a single GPS receiver, J. Geophys. Res., 103, 5019, doi:10.1029/97JB03534, 1998.

Baumann, T., Goree, B., Lovelace, W., Montgomery, P., Ross, G., Walters, D., and Ward, A.: Water Resources Data for Louisiana, Water Year 2005, Water-Data Report LA-05-01, US Geological Survey, Baton Rouge, LA, 2006.

Bawden, G. W., Thatcher, W., Stein, R. S., Hudnut, K. W., and Peltzer, G.: Tectonic contraction across Los Angeles after removal of groundwater pumping effects, Nature, 412, 812-815, doi:10.1038/35090558, 2001.

Bawden, G. W., Johnson, M. R., and Kasmarek, M. C.: Investigation of land subsidence in the Houston-Galveston region of Texas by using the Global Positioning System and Interferometric Synthetic Aperture Radar, 1993-2000, USGS Scientific Investigation Report 2012-5211, US Geological Survey, Reston, VA, 2012.

Beckman, J. D. and Williamson, A. K.: Salt-dome locations in the Gulf Coastal Plain, South-Central United States, WaterResources Investigations Report 90-4060, US Geological Survey, Austin, TX, 1990.

Bertiger, W., Desai, S. D., Haines, B., Harvey, N., Moore, A. W., Owen, S., and Weiss, J. P.: Single receiver phase ambiguity resolution with GPS data, J. Geodyn., 84, 327-337, doi:10.1007/s00190-010-0371-9, 2010.

Blewitt, G. and Lavallée, D.: Effect of annual signals on geodetic velocity, J. Geophys. Res.-Sol. Ea., 107, ETG9-1-ETG 9-11, doi:10.1029/2001JB000570, 2002.

Blewitt, G., Kreemer, C., Hammond, W. C., and Goldfarb, J. M.: Terrestrial reference frame NA12 for crustal deformation studies in North America, J. Geodyn., 72, 11-24, doi:10.1016/j.jog.2013.08.004, 2013.

Blum, M. D., Tomkin, J. H., Purcell, A., and Lancaster, R. R.: Ups and downs of the Mississippi Delta, Geology, 36, 675-678, doi:10.1130/G24728A.1, 2008.

Boehm, J., Niell, A., Tregoning, P., and Schuh, H.: Global Mapping Function (GMF): A new empirical mapping function based on numerical weather model data, Geophys. Res. Lett., 33, L07304, doi:10.1029/2005GL025546, 2006.

Cabral-Cano, E., Dixon, T. H., Miralles-Wilhelm, F., Diaz-Molina, O., Sanchez-Zamora, O., and Carande, R. E.: Space geodetic imaging of rapid ground subsidence in Mexico City, Geol. Soc. Am. Bull., 120, 1556-1566, doi:10.1130/B26001.1, 2008.

Canny, J.: A Computational Approach to Edge Detection, IEEE T. Pattern Anal. Mach. Intell., PAMI-8, 679-698, doi:10.1109/TPAMI.1986.4767851, 1986.

Carrillo, N.: Influence of Artesian Wells in the Sinking of Mexico City, in: Comision Impulsora y Coordinadora de la Investigacion Cientifica, vol. 47, Secretaria de Hacienda y Credito Publico, Mexico, DF, 7-14, 1947.

Chang, C., Mallman, E., and Zoback, M.: Time-dependent subsidence associated with drainage-induced compaction in Gulf of Mexico shales bounding a severely depleted gas reservoir, Am. Assoc. Petrol. Geol. Bull., 98, 1145-1159, doi:10.1306/11111313009, 2014.

Chaussard, E., Wdowinski, S., Cabral-Cano, E. and Amelung, F.: Land subsidence in central Mexico detected by ALOS InSAR time-series, Remote Sens. Environ., 140, 94-106, doi:10.1016/j.rse.2013.08.038, 2014.

Collilieux, X., Métivier, L., Altamimi, Z., Dam, T., and Ray, J.: Quality assessment of GPS reprocessed terrestrial reference frame, GPS Solut., 15, 219-231, doi:10.1007/s10291-010-01846, 2010.

Cuevas, J.: Foundation Conditions in Mexico City, in: Proceedings of International Conference on Soil Mechanics, International Society for Soil Mechanics and Geotechnical Engineering, Cambridge, Mass., 233-237, 1936.

Day, J. W., Pont, D., Hensel, P. F., Ibañez, C., and Ibanez, C.: Impacts of Sea-Level Rise on Deltas in the Gulf of Mexico and the Mediterranean: The Importance of Pulsing Events to Sustainability, Estuaries, 18, 636-647, doi:10.2307/1352382, 1995.

Dixon, T. H., Amelung, F., Ferretti, A., Novali, F., Rocca, F., Dokka, R. K., Sella, G., Kim, S.-W., Wdowinski, S., and Whitman, D.: Space geodesy: subsidence and flooding in New Orleans, Nature, 441, 587-588, doi:10.1038/441587a, 2006.

Dokka, R. K.: Modern-day tectonic subsidence in coastal Louisiana, Geology, 34, 281-284, doi:10.1130/G22264.1, 2006.

Dokka, R. K.: The role of deep processes in late 20th century subsidence of New Orleans and coastal areas of southern Louisiana and Mississippi, J. Geophys. Res., 116, B06403, doi:10.1029/2010JB008008, 2011.

Dokka, R. K., Sella, G. F., and Dixon, T. H.: Tectonic control of subsidence and southward displacement of southeast Louisiana with respect to stable North America, Geophys. Res. Lett., 33, L23308, doi:10.1029/2006GL027250, 2006.

Edrington, C. H., Blum, M. D., Nunn, J. A., and Hanor, J. S.: LongTerm Subsidence and Compaction Rates: A New Model for the Michoud Area, South Louisiana, GCAGS Trans., 58, 261-272, 2008.

Engel, K., Jokiel, D., Kraljevic, A., and Geiger, M.: Big cities. Big water. Big Challenges. Water in an urbanizing world, WWF Germany, Berlin, 2011.

Engelkemeir, R., Khan, S. D., and Burke, K.: Surface deformation in Houston, Texas using GPS, Tectonophysics, 490, 47-54, 2010.

Firuzabadì, D. and King, R. W.: GPS precision as a function of session duration and reference frame using multi-point software, GPS Solut., 16, 191-196, doi:10.1007/s10291-011-0218$8,2011$.

Free ocean tide loading provider: http://holt.oso.chalmers.se/ loading/index.html, last access: 15 January 2015. 
Galloway, D., Jones, D., and Ingebritsen, S.: Land subsidence in the United States, USGS Circular 1182, US Geological Survey, Reston, VA, 1999.

Garrity, C. and Soller, D.: Database of the Geologic Map of North America; adapted from the map by J. C. Reed Jr. and others (2005), US Geological Survey Data Series 424, Reston, VA, 2009.

Harris-Galveston Subsidence District: Harris-Galveston Subsidence District Regulatory Plan 2013, adopted 9 January 2013, amended 8 May 2013, Harris-Galveston Subsidence District, Friendswood, TX, 2013.

Ivins, E. R., Dokka, R. K., and Blom, R. G.: Post-glacial sediment load and subsidence in coastal Louisiana, Geophys. Res. Lett., 34, L16303, doi:10.1029/2007GL030003, 2007.

Jackson, M. P. A. and Seni, S. J.: Geometry and evolution of salt structures in a marginal rift basin of the Gulf of Mexico, east Texas, Geology, 11, 131-135, doi:10.1130/00917613(1983)11<131:GAEOSS>2.0.CO;2, 1983.

Johnson, M. R., Ramage, J. K., and Kasmarek, M. C.: Water-level altitudes 2011 and water-level changes in the Chicot, Evangeline, and Jasper aquifers and compaction 1973-2010 in the Chicot and Evangeline aquifers, Houston-Galveston region, Texas, USGS Sci. Invest. Map 3174, US Geological Survey, Reston, VA, 2011.

Joint Academies Committee on the Mexico City Water Supply, Environment and Resources Commission on Geosciences, National Research Council, A. C. Academia Nacional de la Investigacion Cientifica and A. C. Academia Nacional de Ingenieria: Mexico City's Water Supply: Improving the Outlook for Sustainability, The National Academies Press, Washington, D.C., 1995.

Jurkowski, G., Ni, J., and Brown, L.: Modern uparching of the Gulf Coastal Plain, J. Geophys. Res., 89, 6247-6255, doi:10.1029/JB089iB07p06247, 1984.

Karegar, M. A., Dixon, T. H. and Malservisi, R.: A threedimensional surface velocity field for the Mississippi Delta: Implications for coastal restoration and flood potential, Geology, 43, 519-522, doi:10.1130/G36598.1, 2015.

Kasmarek, M. C., Gabrysch, R. K., and Johnson, M. R.: Estimated land-surface subsidence in Harris County, Texas, 191517 to 2001, USGS Sci. Invest. Map 3097, US Geological Survey, Reston, VA, 2009.

Kasmarek, M. C., Johnson, M. R., and Ramage, J. K.: Water-level altitudes 2010 and water-level changes in the Chicot, Evangeline, and Jasper aquifers and compaction 1973-2009 in the Chicot and Evangeline aquifers, Houston-Galveston region, Texas, USGS Sci. Invest. Map 3138, US Geological Survey, Reston, VA, 2010.

Kasmarek, M. C., Johnson, M. R., and Ramage, J. K.: Water-level altitudes 2012 and water-level changes in the Chicot, Evangeline, and Jasper aquifers and compaction 1973-2011 in the Chicot and Evangeline aquifers, Houston-Galveston region, Texas, USGS Sci. Invest. Map 3230, US Geological Survey, Reston, VA, 2012.

Kasmarek, M. C., Johnson, M. R. and Ramage, J. K.: Water-level altitudes 2013 and water-level changes in the Chicot, Evangeline, and Jasper aquifers and compaction 1973-2012 in the Chicot and Evangeline aquifers, Houston-Galveston region, Texas, USGS Sci. Invest. Map 3263, US Geological Survey, Reston, VA, 2013.

Kearns, T. J., Wang, G., Bao, Y., Jiang, J., and Lee, D.: Current Land Subsidence and Groundwater Level Changes in the Houston Metropolitan Area (2005-2012), J. Surv. Eng., 141, 05015002, doi:10.1061/(ASCE)SU.1943-5428.0000147, 2015.
Kedar, S.: The effect of the second order GPS ionospheric correction on receiver positions, Geophys. Res. Lett., 30, 1829 , doi:10.1029/2003GL017639, 2003.

Khan, S. D., Huang, Z., and Karacay, A.: Study of ground subsidence in northwest Harris county using GPS, LiDAR, and InSAR techniques, Nat. Hazards, 73, 1143-1173, doi:10.1007/s11069014-1067-x, 2014.

Kolker, A. S., Allison, M. A., and Hameed, S.: An evaluation of subsidence rates and sea-level variability in the northern Gulf of Mexico, Geophys. Res. Lett., 38, L21404, doi:10.1029/2011GL049458, 2011.

Lyard, F., Lefevre, F., Letellier, T., and Francis, O.: Modelling the global ocean tides: modern insights from FES2004, Ocean Dynam., 56, 394-415, doi:10.1007/s10236-006-0086-x, 2006.

Meckel, T. A.: An attempt to reconcile subsidence rates determined from various techniques in southern Louisiana, Quaternary Sci. Rev., 27, 1517-1522, doi:10.1016/j.quascirev.2008.04.013, 2008.

Morton, R. A. and Bernier, J. C.: Recent Subsidence-Rate Reductions in the Mississippi Delta and Their Geological Implications, J. Coast. Res., 26, 555-561, doi:10.2112/JCOASTRES-D-0900014R1.1, 2010.

Osmanoglu, B., Dixon, T. H., Wdowinski, S., Cabral-Cano, E., and Jiang, Y.: Mexico City subsidence observed with persistent scatterer InSAR, Int. J. Appl. Earth Obs. Geoinf., 13, 1-12, doi:10.1016/j.jag.2010.05.009, 2011.

Pearson, C. and Snay, R.: Introducing HTDP 3.1 to transform coordinates across time and spatial reference frames, GPS Solut., 17, 1-15, doi:10.1007/s10291-012-0255-y, 2012.

Qu, F., Lu, Z., Zhang, Q., Bawden, G. W., Kim, J.-W., Zhao, C., and Qu, W.: Mapping ground deformation over Houston-Galveston, Texas using multi-temporal InSAR, Remote Sens. Environ., 169, 290-306, doi:10.1016/j.rse.2015.08.027, 2015.

Ramsey, K. E. and Moslow, T. F.: A Numerical Analysis of Subsidence and Sea Level Rise in Louisiana, in Proceedings of Coastal Sediments '87, American Society of Civil Engineers, New Orlean, LA, 1673-1688, 1987.

Rebischung, P., Griffiths, J., Ray, J., Schmid, R., Collilieux, X., and Garayt, B.: IGS08: the IGS realization of ITRF2008, GPS Solut., 16, 483-494, doi:10.1007/s10291-011-0248-2, 2012.

Roberts, H. H., Bailey, A., and Kuecher, G. J.: Subsidence in the Mississippi River Delta; important influences of valley filling by cyclic deposition, primary consolidation phenomena, and early diagenesis, Trans. Gulf Coast Assoc. Geol. Soc., 44, 619-629, 1994.

Schwarz, C.: The North American Datum of 1983, NOAA Professional Paper NOS 2, National Geodetic Information Branch, NOAA, Rockville, Maryland, 1989.

Simms, A. R., Anderson, J. B., DeWitt, R., Lambeck, K., and Purcell, A.: Quantifying rates of coastal subsidence since the last interglacial and the role of sediment loading, Global Planet. Change, 111, 296-308, 2013.

Snay, R. and Soler, T.: Modern Terrestrial Reference Systems. Part 2: The evolution of the NAD83, Prof. Surv., 20, 16-18, 2000.

Sosa-Rodriguez, F.: Exploring the risks of ineffective water supply and sewage disposal: A case study of Mexico City, Environ. Hazards, 9, 135-146, doi:10.3763/ehaz.2010.0016, 2010. 
Thatcher, C. A., Brock, J. C., and Pendleton, E. A.: Economic Vulnerability to Sea-Level Rise Along the Northern U.S. Gulf Coast, J. Coast. Res., 63, 234-243, doi:10.2112/SI63-017.1, 2013.

Törnqvist, T. E., Wallace, D. J., Storms, J. E. A., Wallinga, J., van Dam, R. L., Blaauw, M., Derksen, M. S., Klerks, C. J. W., Meijneken, C., and Snijders, E. M. A.: Mississippi Delta subsidence primarily caused by compaction of Holocene strata, Nat. Geosci., 1, 173-176, doi:10.1038/ngeo129, 2008.

Wang, G.: GPS Landslide Monitoring: Single Base vs. Network Solutions - A case study based on the Puerto Rico and Virgin Islands Permanent GPS Network, J. Geod. Sci., 1, 191-203, doi:10.2478/v10156-010-0022-3, 2011.

Wang, G. and Soler, T.: Using OPUS for Measuring Vertical Displacements in Houston, TX, J. Surv. Eng., 139, 126-134, doi:10.1061/(ASCE)SU.1943-5428.0000103, 2013.

Wang, G. and Soler, T.: Measuring Land Subsidence Using GPS: Ellipsoid Height versus Orthometric Height, J. Surv. Eng., 14, 05014004-1-05014004-12, doi:10.1061/(ASCE)SU.19435428.0000137, 2014.

Wang, G., Yu, J., Ortega, J., Saenz, G., Burrough, T., and Neill, R.: A Stable Reference Frame for the Study of Ground Deformation in the Houston Metropolitan Area, Texas, J. Geod. Sci., 3, 188202, doi:10.2478/jogs-2013-0021, 2013.

Wang, G., Kearns, T. J., Yu, J., and Saenz, G.: A stable reference frame for landslide monitoring using GPS in the Puerto Rico and Virgin Islands region, Landslides, 11, 119-129, doi:10.1007/s10346-013-0428-y, 2014.

Wang, G., Bao, Y., Cuddus, Y., Jia, X., Serna, J., and Jing, Q.: A methodology to derive precise landslide displacement time series from continuous GPS observations in tectonically active and cold regions: a case study in Alaska, Nat. Hazards, 77, 1939-1961, doi:10.1007/s11069-015-1684-z, 2015a.
Wang, G., Welch, J., Kearns, T. J., Yang, L., and Serna, J.: Introduction to GPS geodetic infrastructure for land subsidence monitoring in Houston, Texas, U.S.A., in: Ninth International Symposium on Land Subsidence, UNESCO Working Group on Land Subsidence, Nagoya, Japan, 2015b.

Williams, S., Stone, G., and Burruss, A.: A perspective on the Louisiana wetland loss and coastal erosion problem, J. Coast. Res., 13, 593-594, 1997.

Wolstencroft, M., Shen, Z., Törnqvist, T. E., Milne, G. A., and Kulp, M.: Understanding subsidence in the Mississippi Delta region due to sediment, ice, and ocean loading: Insights from geophysical modeling, J. Geophys. Res.-Solid Ea., 119, 3838-3856, doi:10.1002/2013JB010928, 2014.

Yu, J., Wang, G., Kearns, T. J., and Yang, L.: Is There Deep-Seated Subsidence in the Houston-Galveston Area?, Int. J. Geophys., 2014, 1-11, doi:10.1155/2014/942834, 2014.

Yu, S.-Y., Törnqvist, T. E., and Hu, P.: Quantifying Holocene lithospheric subsidence rates underneath the Mississippi Delta, Earth Planet. Sc. Lett., 331-332, 21-30, doi:10.1016/j.epsl.2012.02.021, 2012.

Zilkoski, D., Hall, L., Mitchell, G., Kammula, V., Singh, A., Chrismer, W., and Neighbors, R.: The Harris-Galveston Coastal Subsidence District/National Geodetic Survey automated Global Positioning System subsidence monitoring Project, in: Proceedings of the US Geological Survey Subsidence Interest Group Conference, US Geological Survey, Galveston, TX, 13-28, 2003.

Zumberge, J. F., Heflin, M. B., Jefferson, D. C., Watkins, M. M., and Webb, F. H.: Precise point positioning for the efficient and robust analysis of GPS data from large networks, J. Geophys. Res., 102, 5005-5017, doi:10.1029/96JB03860, 1997. 